\title{
ALTERASI HIDROTERMAL GUNUNG RENDINGAN BERDASARKAN ANALISIS PETROGRAFI DAN X-RAY DIFFRACTION (XRD)
}

\section{HYDROTHERMAL ALTERATION IN MOUNT RENDINGAN BASED ON PETROGRAPHY AND X-RAY DIFFRACTION (XRD) ANALYSIS}

\author{
Dewi Gentana ${ }^{1}$, Nana Sulaksana ${ }^{2}$, Emi Sukiyah ${ }^{3}$, dan Euis T. Yuningsih ${ }^{3}$ \\ ${ }^{1}$ Program Doktoral Fakultas Teknik Geologi, Universitas Padjadjaran \\ 2Departemen Geologi Terapan, Fakultas Teknik Geologi, Universitas Padjadjaran \\ ${ }^{3}$ Departemen Geologi Sains, Fakultas Teknik Geologi, Universitas Padjadjaran \\ dewigentana06@gmail.com
}

\section{ABSTRAK}

Daerah penelitian terletak di daerah panas bumi Gunung Rendingan, Kabupaten Tanggamus, Provinsi Lampung. Daerah penelitian dipengaruhi oleh Sesar Semangko, mempunyai pola sesar berarah Barat Laut -Tenggara dan Timur Laut - Barat Daya. Penelitian bertujuan untuk mengetahui himpunan mineral alterasi berdasarkan analisis petrografi dan $X$-Ray Diffraction (XRD). Analisis petrografi digunakan untuk mengetahui mineral alterasi sebagai indikator temperatur dan fluida hidrothermal di daerah penelitian. Analisis XRD dilakukan untuk mengindentifikasi jenis mineral lempung. Berdasarkan analisis petrografi dan XRD pada batuan permukaan di daerah penelitian menghadirkan mineral kelompok lempung yang terdiri dari smektit, ilit, serisit dan kaolinit. Hasil analisis petrografi dan XRD terhadap serbuk bor (cutting) dari sumur XD-1, XD-2 dan XD-3 memperlihatkan himpunan mineral alterasi hidrotermal smektit-kaolinit-serisit dan ilit-epidot pada sumur XD-1, himpunan mineral serisitsmektit, smektit-ilit dan ilit-epidot pada sumur XD-2, himpunan mineral smektit-kaolinit dan ilitsmektit-epidot pada sumur XD-3. Berdasarkan himpunan mineral alterasi tersebut dapat diperkirakan temperatur bawah permukaan di daerah penelitian berkisar $150^{\circ}-300^{\circ} \mathrm{C}$ pada kedalaman 700 - 1900 mKu sebagai zona reservoir. Kehadiran mineral kalk-silikat yaitu epidot bersama wairaikit dan prehnit sebagai indikator zona reservoir memiliki temperatur yang baik. Batuan di daerah penelitian memiliki permeabilitas yang baik dengan kehadiran mineral adularia.

Kata kunci: Himpunan Mineral Alterasi, Panas Bumi, Petrografi, Sumatera XRD

\section{ABSTRACT}

The research area is located in the geothermal area of Mt. Rendingan, Tanggamus Regency, and Lampung Province. The research area was influenced by the Semangko Fault, having Northwest-Southeast and Northeast-Southwest fault pattern. The study aims to determine the alteration minerals assemblages based on Petrographic and X-Ray Diffraction (XRD) Analysis. Petrographic analysis was used to determine alteration minerals as indicators of temperature and hydrothermal fluid in the reserach area. XRD analysis was performed to identify the type of clay minerals. Based on petrographic and XRD analysis on surface rocks in the research area present clay group minerals: smectite, ilite, sericite and kaolinite. The results of petrographic and XRD analysis of cutting from wells XD-1, XD-2 and XD-3 showed a hydrothermal alteration minerals assemblage such as smectite-kaolinite-sericite and iliteepidote in XD-1 wells, a sericite-smectite, smectite-ilite and illite-epidote in XD-2 wells, smectite-kaolinite minerals and illite-smectite-epidote minerals assemblage in XD-3 wells. Based on the assemblage of alteration minerals it can be estimated the subsurface temperature in the reserach area from $150^{\circ}-300{ }^{\circ} \mathrm{C}$ in ranges at depth of $700-1900 \mathrm{mKu}$ as a reservoir zone. The presence of calc-silicate minerals namely epidote with wairaikit and prehnite as reservoir zone indicators which have a good temperatures. The rocks in the 
reserach area have a good permeability which is characterized by the presence of adularia minerals.

Keywords: Alteration mineral assemblages, geothermal, petrographic, Sumatra, XRD

\section{PENDAHULUAN}

Daerah penelitian merupakan daerah panas bumi Gunung Rendingan yang secara administratif termasuk ke dalam wilayah Kabupaten Tanggamus, Provinsi Lampung, Sumatra bagian Selatan. Secara geografis berada pada koordinat $104^{\circ} 29^{\prime} 20,9^{\prime \prime}$ BT hingga 104³8'37,15" BT dan $5^{\circ} 16^{\prime} 14,47^{\prime \prime}$ LS hingga $5^{\circ} 31^{\prime} 4,35^{\prime \prime}$ LS. Daerah penelitian terbentuk dari suatu rangkaian kejadian regional tektonovulkanik yang runtuh (collapse) membentuk depresi (Van Bemmelen, 1949). Kegiatan tektonik yang berkembang berasal dari suatu mata rantai kejadian regional tersebut telah mengalami segmentasi. Di sekitar Sumatra Selatan hingga Teluk Semangko sesar ini dikenal sebagai sistim Sesar Semangko. Pulau Sumatra membentuk sesar-sesar Semangko yang bersambung dari Utara ke Selatan yang dikenal dengan Sistim Sesar Semangko (Semangko Fault System). Secara fisiografis daerah penelitian termasuk ke dalam zona sesar Semangko Selatan yang merupakan daerah depresi sepanjang Bukit Barisan yang mempunyai arah Barat LautTenggara (NW-SE) membujur dari Teluk Semangko hingga Banda Aceh (Van Bemmelen, 1949). Kehadiran sesar-sesar dekstral yang berarah Barat LautTenggara (NW-SE) sangat berperan sebagai zona permeabilitas yang menyebabkan terdapat manisfestasi panas bumi di permukaan. Hal ini mengindikasikan bahwa ada sumber panas di kedalaman membentuk suatu sistem panas bumi (reservoir) yang dapat dikembangkan sebagai sumber energi panas bumi. Aktivitas sistem panas bumi umumnya berkaitan dengan pembentukan mineral alterasi hidrotermal. Suatu lapangan panas bumi dapat diproduksi secara maksimal apabila telah diketahui karakteristik sistem panas bumi. Mineral alterasi hidrotermal dapat dipergunakan sebagai salah satu indikator untuk mengetahui suatu daerah yang mempunyai potensi panas bumi. Alterasi hidrotermal merupakan ciri adanya perubahan tekstur, mineralogi, dan komposisi kimia dari suatu batuan yang diakibatkan oleh aktivitas fluida hidrothermal, Hochstein dan Browne (2000). Alterasi hidrotermal digunakan untuk mengetahui mineral ubahan serta mengestimasi tingkat keasaman fluida (Yosana, 2017). Guilbert dan Park (1986) proses hidrotermal pada keseimbangan tertentu akan menghasilkan kumpulan mineral tertentu sebagai himpunan mineral (mineral assemblage).

Penelitian ini bertujuan untuk mengetahui himpunan mineral alterasi hidrotermal berdasarkan analisis petrologi yaitu petrografi dan $X$-Ray Diffraction (XRD) yang dilakukan terhadap sampel batuan permukaan dan bawah permukaan (sumur) untuk memprediksi temperatur bawah permukaan (reservoir) panas bumi di daerah penelitian.

\section{Geologi Daerah Penelitian}

Geologi regional di daerah penelitian berdasarkan peneliti terdahulu tersusun oleh batuan yang berumur Tersier hingga Kuarter (Masdjuk, 1990). Litologi di daerah penelitian didominasi oleh produk vulkanik Kuarter terdiri dari 8 (delapan) satuan batuan. Aluvium sebagai endapan termuda dijumpai di bagian Barat Daya dan Selatan daerah penelitian. Produk vulkanik Tersier terdiri dari 3 (tiga) satuan batuan dari muda ke tua yaitu lava andesit Gunung Kukusan, lava andesit dan tuf pumice Gunung Sula. Berdasarkan analisis umur batuan (age dating) memperlihatkan batuan tertua berumur Tersier dengan umur berkisar dari 3.94-4.53 $\times 10^{6}$ tahun. Batuan yang berumur Kuarter mempunyai umur berkisar dari 1.41$1.75 \times 10^{6}$ tahun (Masdjuk, 1990). Lava andesit sebagai batuan tertua yang berasal dari Gunung Sula secara megaskopis berwarna abu-abu kehitaman, fenokris 
plagioklas, satuan batuan andesit ini tidak mengalami alterasi dan satuan batuan ini berumur sekitar $4.53 \mathrm{x} 10^{6}$ tahun atau sekitar Pliosen Tengah. Satuan lava Andesit basaltik yang diperkirakan berasal dari Gunung Kukusan merupakan batuan kedua tertua di daerah penelitian. Satuan batuan ini berwarna hitam hingga abu-abu, bertekstur porfiri-afanatik dengan kompisisi plagioklas dan piroksin Batuan lava andesit di wilayah Gunung Kukusan ini berumur 3.93x $10^{6}$ tahun atau sekitar Pliosen Atas. Lava dasit yang tersingkap di sekitar Gunung Duduk yang berumur

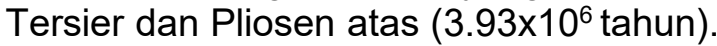
Pada batuan ini telah mengalami pelapukan, sehingga memiliki warna abuabu keputihan, sebagai fenokris mineral plagioklas, hornblenda, dan mineral opak (pirit) yang terdapat di dalam masa dasar gelas. Satuan batuan piroklastik yang bersumber dari Gunung Kebawok, terdiri dari piroklastik berwarna coklat kekuningan hingga abu-abu, breksi tuf yang telah mengalami proses pelapukan yang cukup tinggi bersifat sangat lunak. Umur batuan ini $1.75 \times 10^{6}$ tahun atau sekitar Pleistosen Bawah. Batuan piroklastik berasal dari Gunung Rendingan, memiliki warna putih kecoklatan sampai kekuningan, tidak terkompaksi dengan baik, diperkirakan umurnya $1.41 \times 10^{6}$ tahun atau sekitar Pleistosen Tengah. Batuan piroklastik tuf tertutupi oleh satuan lava andesit basaltik yang merupakan produk dari vulkanik Gunung Rendingan. Lava memiliki warna abu - abu gelap, bertekstur porfiritikafanitik, didominasi oleh mikrolit plagioklas, struktur aliran, dan vesikular yang berorientasi. Satuan breksi laharik andesit basaltik memiliki warna abu-abu gelap, bertekstur afanitik. Batuan sebagai fragmen breksi memperlihatkan struktur aliran dan vesikular yang berorientasi. Satuan batuan ini diperkirakan juga berasal dari Gunung Rendingan.

Secara spesifik di daerah penelitian berkembang sesar-sesar yang terlokalisir dalam suatu daerah depresi akibat gerakan tektonik regional Semangko yang bergerak untuk mencari posisi keseimbangan yang menghasilkan permeabilitas pada batuan yang dilaluinya (Kamah, 2001). Perkembangan struktur geologi di daerah penelitian diperlihatkan oleh sesar-sesar yang memiliki arah Barat Laut - Tenggara (NW-SE) dan Timur Laut - Barat Daya (NESW) serta fenomena kawah dan daerah depresi merupakan sisa kaldera gunungapi yang berperan terhadap kemunculan manifestasi panas bumi. Keberadaan manifestasi panas bumi di daerah penelitian, umumnya terdapat pada daerah depresi, zona tepi atau perpotongan sesar berupa mata air panas/ hangat, fumarol, solfatara, kubangan lumpur panas (mud pool), tanah beruap (steaming ground), uap air panas (steam heated water), dan batuan alterasi tersebar di bagian tengah dan Selatan daerah penelitian. Di beberapa tempat terdapat silika residu dan travertin. Peta geologi regional dan penampang geologi yang memperlihatkan adanya manifestasi panas bumi permukaan ditampilkan pada Gambar 1. 


\section{MAKALAH ILMIAH}

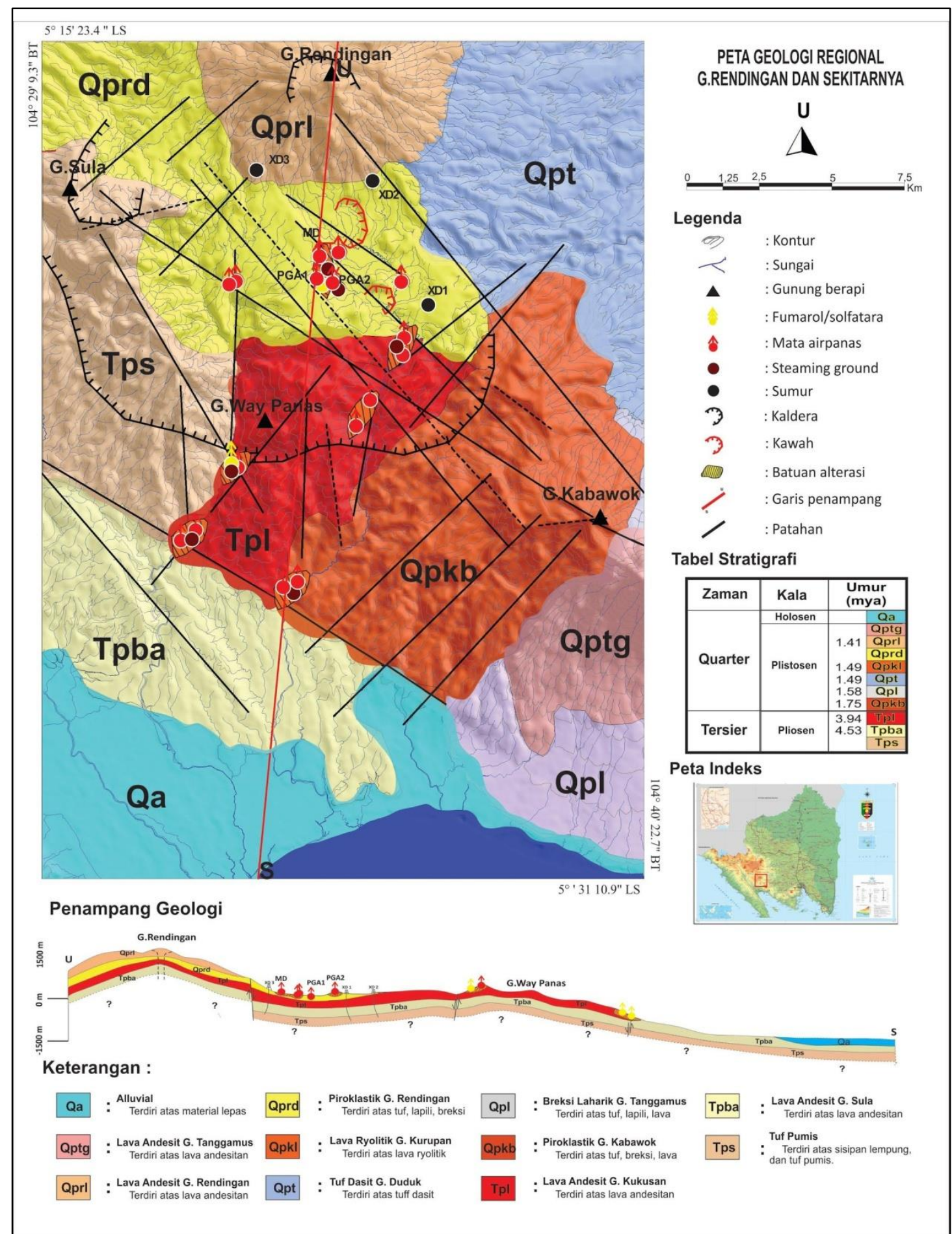

Gambar 1. Peta dan penampang geologi Utara-Selatan (A-B), memperlihatkan keberadaan manifestasi panas bumi di daerah penelitian umumnya berada pada daerah depresi, pada tepi atau perpotongan patahan

\section{METODOLOGI}

Metode yang digunakan adalah penelitian lapangan dan penelitian laboratorium. Penelitian lapangan merupakan pengamatan visual terhadap manifestasi panas bumi permukaan, khususnya untuk pengamatan litologi berkaitan dengan keterdapatan batuan alterasi yang akan menggambarkan himpunan mineral alterasi hidrothermal. Penelitian laboratorium berupa analisis petrologi meliputi analisis 
petrografi dengan menggunakan mikroskop polarisasi dan $X$-Ray Diffraction (XRD). Analisis petrografi dan XRD dilakukan pada sampel batuan permukaan dari 3 (tiga) daerah di lokasi penelitian yaitu daerah Pagar Alam 1 (PGA-1), Pagar Alam 2 (PGA-2) dan Muara Dua (MD). Analisis petrografi dan XRD juga dilakukan pada sampel batuan serbuk bor (cutting) dari sumur pengeboran XD-1, XD-2 dan XD3.

\section{HASIL DAN PEMBAHASAN}

\section{HASIL}

\section{Litologi Dan Manisfestasi panas bumi Permukaan}

Litologi daerah penelitian ini mencakup daerah Pagar Alam (PGA-1), Pagar Alam 2 (PGA-2) dan Muara Dua (MD) tersusun oleh batuan produk vulkanik berupa lava, piroklastik berupa tuf dan breksi vulkanik yang telah teralterasi secara argillicpropylitic ditandai dengan mineral kaolinit yang mengindikasikan lingkungan asam. Di ke 3 (tiga) daerah pengamatan tersebut terdapat manisfestasi panas bumi permukaan berupa mata air panas/hangat, fumarol, solfatara, kubangan lumpur panas (mud pool), tanah panas beruap (steaming ground), uap air panas (steam heated water), dan batuan alterasi.

\section{Daerah Pagar Alam 1}

Pada daerah Pagar Alam 1 (PGA-1), hasil observasi pengamatan visual di lapangan, litologi produk vulkanik (lava andesitbasaltik) berwarna abu-abu muda hingga putih, telah mengalami pelapukan dan terubah kuat sehingga sulit untuk dikenali tekstur batuan asal. Manifestasi panas bumi permukaan berupa steaming ground, fumarol, mud pool, mata air panas dan batuan alterasi, berbau belerang. Mata air panas memiliki temperatur $80,8^{\circ} \mathrm{C}$ dengan $\mathrm{pH}$ 2. Dibeberapa lokasi terdapat mudpool memiliki temperatur $97,2^{\circ} \mathrm{C}$ dan $\mathrm{pH} 3$ (Gambar 2). Pada lokasi ini terdapat adanya endapan silika residu (putih), jarosit (hitam) dan sulfur (kuning).

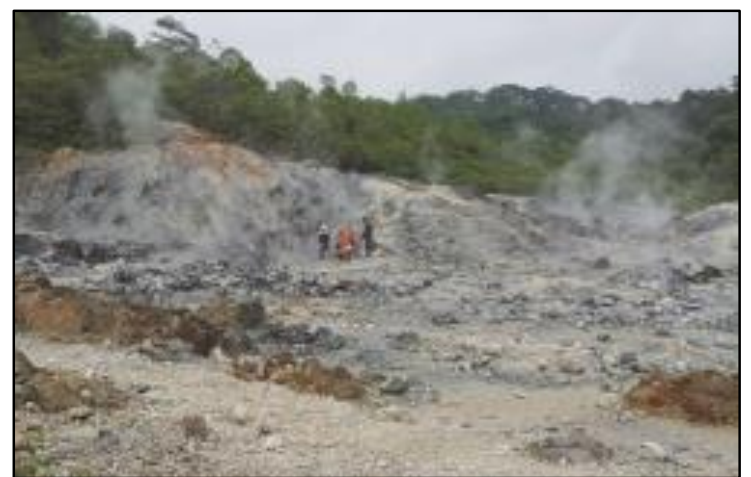

Gambar 2. Manifestasi panas bumi daerah PGA-1, berupa batuan alterasi, fumarol, solfatar dan streaming ground.

\section{Daerah Pagar Alam 2}

Pada daerah Pagar Alam 2 (PGA-2), hasil observasi pengamatan visual di lapangan dijumpai batuan piroklastik, tuf dan breksi yang telah mengalami proses alterasi yang sangat kuat menjadi kaolinit, berwarna putih kecoklatan lengket (sticky). Terdapat manifestasi panas bumi permukaan berupa fumarol, solfatara, berbau belerang tajam, steaming ground, batuan alterasi, mata air panas dengan gelembung - gelembung gas pada dasar sungai dan $\mathrm{pH}$ air 3 . Di lokasi ini juga dijumpai mudpool memiliki temperatur $97,2^{\circ} \mathrm{C}$, steaming ground memiliki temperatur $93^{\circ} \mathrm{C}$.(Gambar 3).

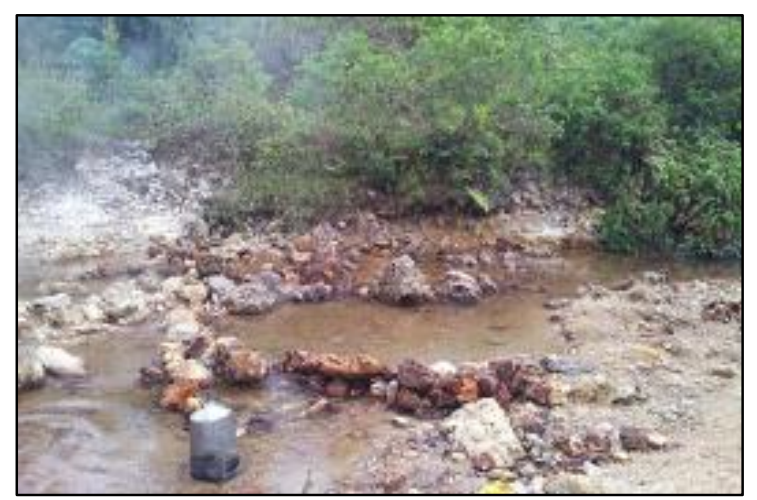

Gambar 3. Manisfestasi panas bumi daerah PGA-2 berupa fumarol/solfatar, mud pool, steaming ground dan mata air panas dengan gelembung-gelebung gas pada dasar sungai.

\section{Daerah Muara Dua}

Pada daerah Muara Dua (MD), hasil observasi pengamatan visual di lapangan terdapat batuan piroklastik berupa tuf, breksi dan lava andesit yang telah 
teralterasi kuat secara argillic ditandai dengan mineral kaolinit. Hamparan batuan alterasi luas disepanjang sungai, berwarna putih kecoklatan lengket (sticky). Hamparan batuan alterasi dengan steaming ground memiliki temperatur $94,8^{\circ} \mathrm{C}$. Manifestasi panas bumi permukaan lainnya berupa mudpool, fumarol, solfatar, berbau belerang, mata air panas memiliki temperatur $97^{\circ} \mathrm{C}$ dengan $\mathrm{pH}$ air 4. Steam heated water membentuk danau, air danau berwarna bening kehijauan, berbau belerang, memiliki temperatur $39,9^{\circ} \mathrm{C}$. Rendahnya temperatur air danau mengindikasikan bahwa air panas di daerah ini telah tercampur dengan air permukaan (Gambar 4).

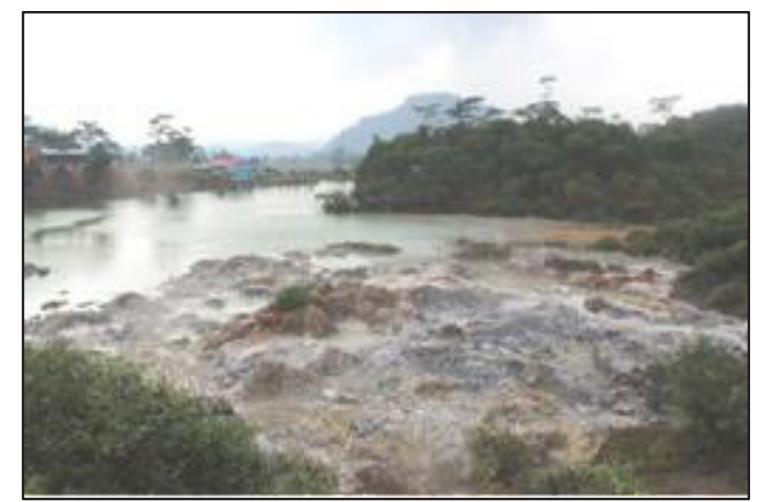

Gambar 4. Manisfestasi panas bumi MD berupa steam heatedwater, batuan alterasi, steaming ground, fumarol solfatar

\section{Karakteristik Mineral Alterasi}

Hasil analisis petrografi terhadap sampel batuan yang diambil dari daerah Pagar Alam 1 (PGA-1) telah mengalami intensitas alterasi hidrotermal mencapai $100 \%$ dan pelapukan yang cukup tinggi, sehingga sulit untuk mengenali jenis dan tekstur batuan asal, memperlihatkan warna putih kecoklatan (//-Nikol) dan kuning kecoklatan (X-Nikol). Sayatan tipis tersusun oleh mineral kuarsa sekunder (45\%) dengan tekstur colloform, oksida besi $(20 \%)$, mineral opak (15\%) smektit $(10 \%)$, anhidrit (10\%). Adanya tekstur colloform mencerminkan proses pengendapan mineral kuarsa sekunder. Terdapat mineral smektit mengisi mineral (vein mineral) (Gambar 5).

Hasil analisis petrografi sampel batuan permukaan daerah Pagar Alam 2 (PGA-2) dalam sayatan tipis memperlihatkan warna hitam kecoklatan (//-Nikol) dan hitam (XNikol). Tekstur awal batuan sangat sulit dikenali batuan telah mengalami alterasi yang sangat kuat dengan intensitas alterasi mencapai $100 \%$.

Kenampakan mikroskopis pada sayatan tipis sampel PGA-2 tersusun didominasi oleh mineral lempung (96\%), piroksin (2\%) dan pecahan mineral kuarsa (2\%), tersebar tidak merata (Gambar 6). Secara mikroskopis, bertekstur afanitik derajat kristalisasi hipokristalin, bentuk kristal subhedral-anhedral, fenokris tersusun oleh mineral plagioklas $(10 \%)$ terubah menjadi mineral oksida $(10 \%)$, smektit $(15 \%)$, dan mineral opak (20\%). Mineral smektit dijumpai sebagai vein mineral dan hadir juga mengubah masa dasar dan fenokris plagioklas $(10 \%)$ dengan total masa dasar (35\%). Pada sayatan tipis mineral primer plagioklas dan piroksen, dengan masa dasar berupa mineral sekunder berupa mineral opak, smektit dan oksida masih dapat dikenali dengan tingkat intensitas ubahan sedang (45\%). Mineral smektit dijumpai juga sebagai vein mineral dan masa dasar (Gambar 7). 


\section{MAKALAH ILMIAH}

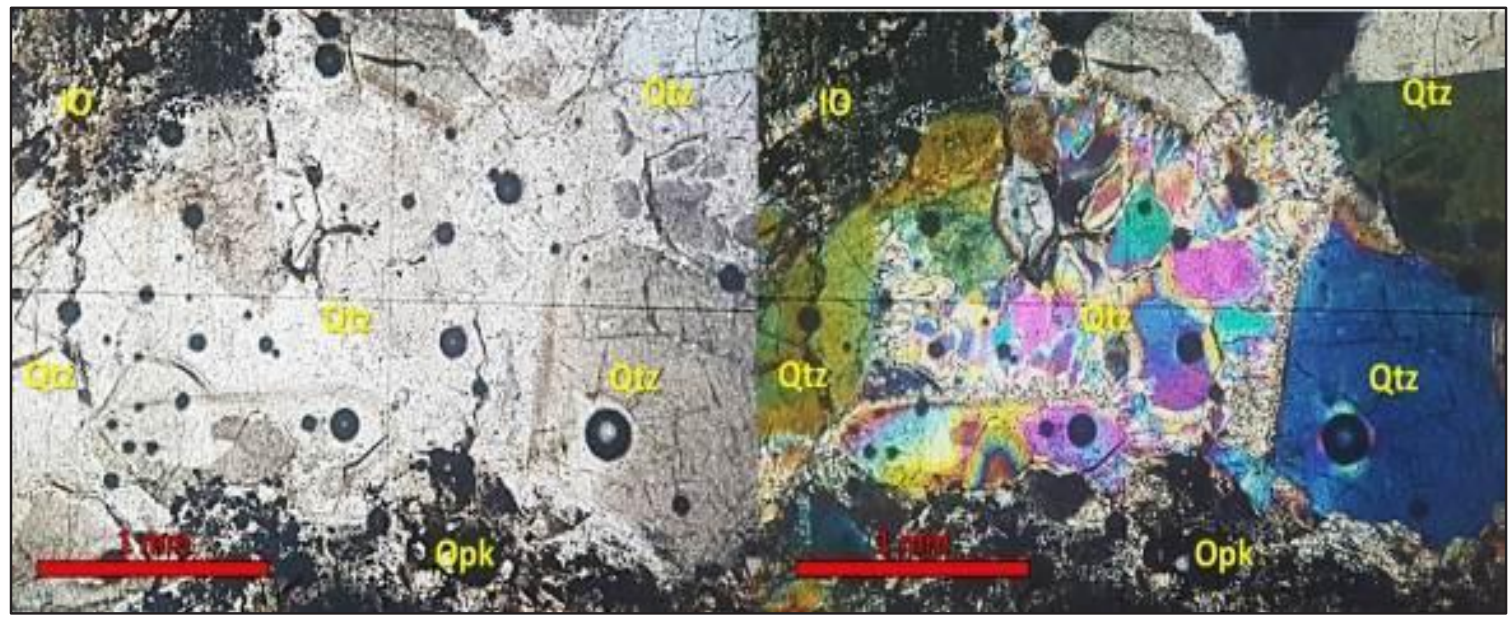

Gambar 5. Kenampakan pagioklas terubah menjadi mineral lempung, klorit bersama mineral kuarsa sekunder pada sampel batuan PGA-1, perbesaran 40x. Kiri //-Nikol. Kanan X-Nikol

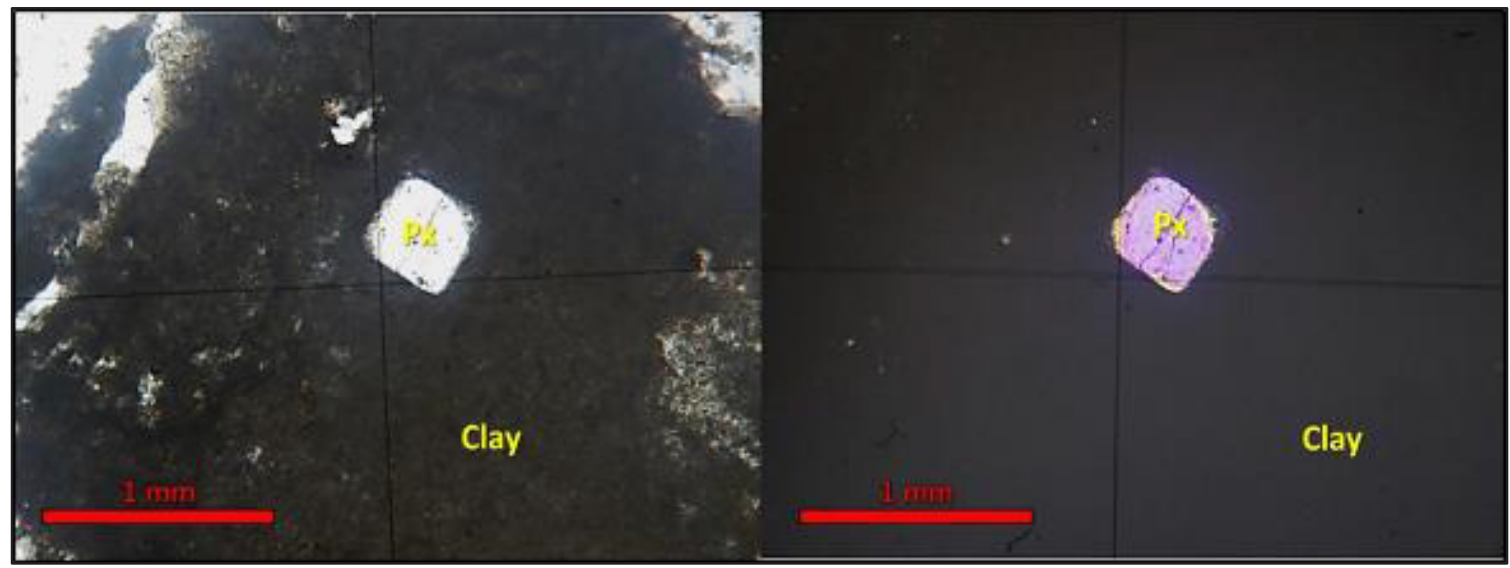

Gambar 6. Kenampakan fragmen mineral piroksin dalam matriks mineral lempung yang berlimpah, menunjukan batuan telah mengalami terubah kuat. Sampel batuan PGA-2, perbesaran 40 x. Kiri //-Nikol. Kanan X-Nikol.

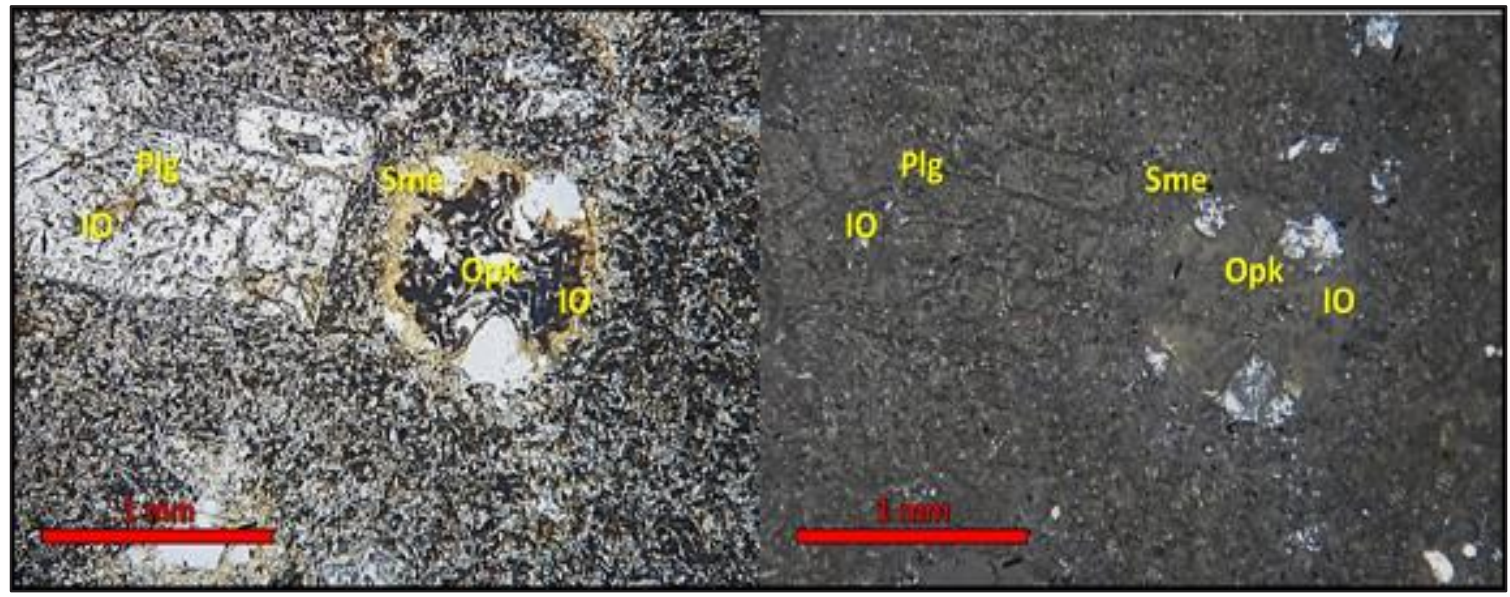

Gambar 7. Kenampakan mineral kuarsa sekunder polikristalin mengisi rongga batuan.Terdapat mineral smektit (Sme) menggantikan masa dasar. Kehadiran oksida besi (IO) bersama mineral opak pada sampel batuan MD, perbesaran 40x. Kiri //-Nikol. KananX-Nikol. 


\section{MAKALAH ILMIAH}

\section{Himpunan Mineral Alterasi Sumur XD-1}

\section{Himpunan Mineral Smektit-Kaolinit-} Serisit Himpunan mineral ini terdapat pada sampel cutting interval kedalaman 100-818 mKu. Secara mikroskopis sayatan cutting terdiri dari fragmen andesit aliran, andesit porfiritik dan tuf, yang umumnya telah teralterasi dengan intensitas rendah-sedang (20-50\%). Terdapat mineral sekunder yaitu mineral lempung kaolin dan serisit menggantikan plagioklas, kuarsa dan gelas dan juga sebagai masa dasar berwarna coklat keruh. Mineral sekunder lainnya dijumpai pada kedalaman ini yaitu kalsit, zeolit, idingsit, piropilit. Mineral opak dan sfen hadir berupa agregat halus mengganikan masa dasar pada andesit aliran, porfiritik dan tuf. Pada kedalaman 501-598mKu hadirnya mineral epidot bersama ilit sebagai relict mineral.

Himpunan Mineral Alterasi Ilit-Epidot. Himpunan mineral ini terdapat pada litologi andesit aliran, andesit porfiritik dan tuf yang telah teralterasi dengan intensitas sedang-kuat $(30-70 \%)$, pada interval kedalaman 908-1980 mKu. Pada kedalaman ini terdapat mineral sekunder dengan kehadiran mineral ilit bersama mineral kalsit, piropilit, kuarsa, zeolit, klorit dan sfen. Mineral klorit, kalsit dan sfen terlihat menggantikan mineral plagioklas, feldspar, dan hadir sebagai agregat dan menggantikan masa dasar di dalam tuf, andesit porfiritik dan andesit aliran. Pada kedalaman ini terdapat mineral opak tersebar tidak merata berbentuk prismatik dan sebagai agregat halus menimpa mineral lempung, kuarsa dan sfen. Mineral smektit-ilit terdapat pada interval kedalaman 903-1104mKu, pada litologi andesit porfiritik. Mineral kalsit dijumpai melimpah sebagai masa dasar dan fenokris pada andesit porfiritik. Feldspar sekunder hadir bersama zeolit. Zeolit bias rangkap rendah hadir bersama mineral lempung. Mineral sfen mempunyai bias rangkap tinggi hadir bersama mineral opak. Mineral ilit hadir kembali di kedalaman 1659 mKu. Mineral epidot hadir bersama klorit pada interval kedalaman 1800-1980 mKu. Klorit dijumpai melimpah merubah feldspar pada litologi andesit porfiri. Analisis mikroskopis cutting sumur XD1 pada kedalaman 501 $\mathrm{mKu}$ memperlihatkan mineral smektit mengubah masa dasar batuan (Gambar 8).

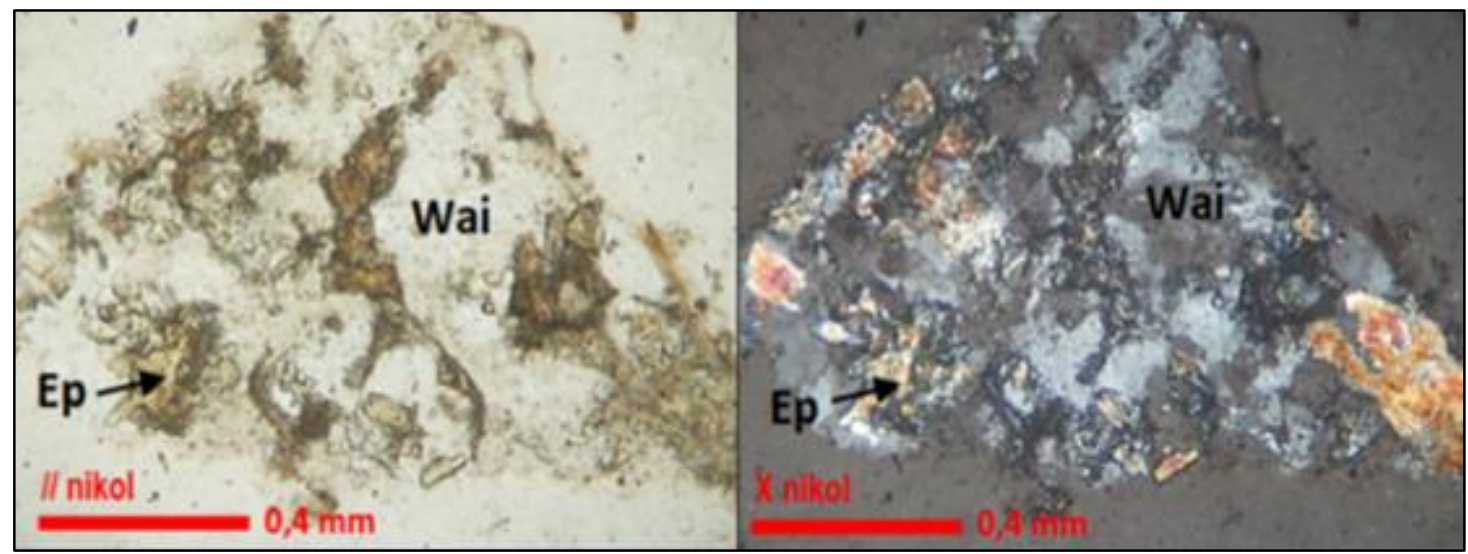

Gambar 8. Kenampakan mikroskopis, fragmen andesit aliran pada kedalaman $501 \mathrm{mKu}$, sampel cutting sumur XD-1. Plagioklas terubah menjadi epidot (Ep), masa dasar terubah menjadi mineral lempung Wairakit (Wai). Kehadiran epidot pada kedalam ini diperkirakan sebagai relict mineral dan llit (III) dan klorit (Chl). PPL (Paralel Nicol); XPL (Cross Nicol) sumur XD1 


\section{Himpunan Mineral Alterasi XD-2}

\section{Himpunan Mineral Alterasi Smektit-} Serisit. Himpunan mineral ini terdapat pada sampel cutting interval kedalaman 128-518 mKu pada litologi tuf litik terubah (60-80\%), fragmen andesit terubah (20$30 \%$ ) dan basalt terubah (10\%). Tuf litik warna abu-abu - merah kecoklatan. Terdapat andesit sebagai fragmen pada tuf litik terubah menjadi mineral smektit dan oksida besi. Oksida besi berwarna coklat kemerahan sebagai matrik dan vein mineral. Mineral smektit hadir bersama serisit menggantikan fenokris dan matriks plagioklas. Mineral sekunder lainnya pada kedalaman ini yaitu mineral opak berwarna hitam dan smektit berwarna coklat hadir merubah plagioklas (matriks) dan serisit berwarna putih kecoklatan bias rangkap tinggi, merubah plagioklas fenokris dan matrik.

\section{Himpunan Mineral Smektit-llit.} Himpunan mineral ini terdapat pada sampel serbuk bor (cutting) interval kedalaman 519- 908mKu pada litologi tuf litik terubah, basalt terubah dan andesit terubah. Mineral sekunder (clay mineral) yang hadir pada kedalaman ini yaitu smektit dan ilit. Mineral sekunder lainnya antara lain klorit, kalsit, kuarsa sekunder, opak dan oksida besi. Mineral opak hadir tersebar merubah masa dasar batuan dan mineral klorit terlihat hadir mengubah plagioklas dan masa dasar batuan bersama mineral lempung.

Himpunan Mineral Alterasi Ilit-Epidot. Himpunan mineral ini terdapat pada sampel cutting interval 909-1748 mKu pada litologi tuf litik terubah dan tuf kristal terubah (interval kedalaman 909-1028mKu), andesit terubah terdapat pada interval kedalaman $1271-1301 \mathrm{mKu}$. Terdapat andesit terubah bersama lempung hitam dan graywacke terubah pada interval kedalaman 1301$1451 \mathrm{mKu}$. Pada interval kedalaman 14521748mKu dijumpai kembali andesit terubah. Mineral sekunder lempung yang hadir pada himpunan mineral ini yaitu mineral ilit dijumpai mulai kedalaman $908 \mathrm{mKu}$. Mineral sekunder lainnya yaitu klorit, kalsit, epidot dan kuarsa sekunder. Kenampakan mineral epidot hadir mengubah plagioklas dan mengisi urat pada fragmen batuan mulai dijumpai pada kedalaman $1499 \mathrm{mKu}$. Klorit hadir merubah masa dasar dan plagioklas. Kehadiran mineral kuarsa sekunder, oksida besi, kalsit, klorit, ilit dan epidot selain menggantikan plagioklas dan masa dasar juga terdapat sebagai vein mineral mengisi rekahan pada fragmen tuf dan fragmen andesit. Intensitas ubahan pada cutting sumur XD-2 secara keseluruhan rendah hingga sedang (2245\%). Dari kenampakan mikroskopis (petrografi) cutting sumur XD2 pada kedalaman 1499 mKu memperlihatkan kehadiran mineral wairakit bersama epidot (Gambar 9).

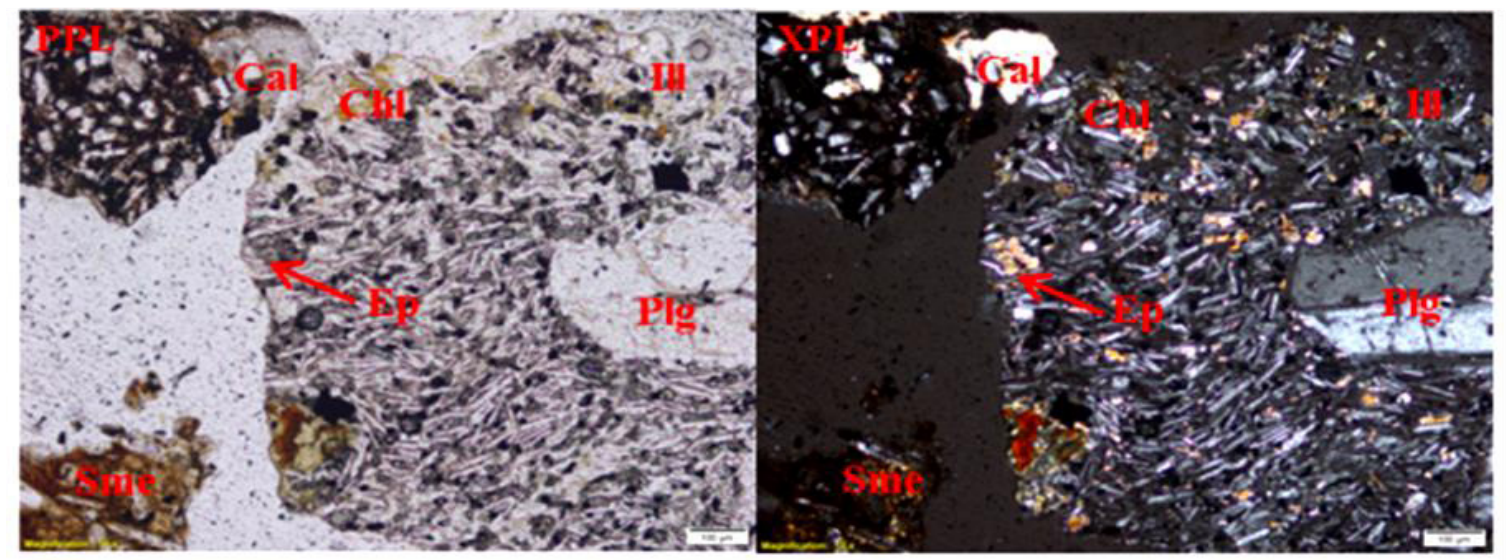

Gambar 9. Kenampakan mikroskopis, fragmen andesit pada kedalaman $1499 \mathrm{mKu}$, sampel cutting sumur XD-2. Plagioklas terubah menjadi llit, smektit (Sme), epidot (Ep) dan kalsit (Cal). PPL (Paralel Nicol), XPL (Cross Nicol). 
Pada sumur XD2 terjadi hilang sirkulasi (loss circulation) mulai interval kedalaman 690-800mKu dan hilang sirkulasi berulang pada interval kedalaman 1299-1342 mKu, 1411-1448 mKu, 1510-1528 mKu, 1528$1551 \mathrm{mKu}, 1551-1574 \mathrm{mKu}, 1574-1603$ $\mathrm{mKu}, 1633-1722 \mathrm{mKu}$. Hilang sirkulasi pada kedalaman tersebut di atas berkisar dari 0,6-20 Barel Per Minutes (BPM).

\section{Himpunan Mineral Alterasi XD-3}

Himpunan Mineral Alterasi SmektitKaolinit. Himpunan mineral ini terdapat pada sampel cutting interval kedalaman 175-650mKu pada litologi breksi vulkanik terubah. Pada kedalaman $247-375 \mathrm{mKu}$ terdapat tuf teralterasi. Umumnya batuan telah mengalami alterasi dengan intensitas alterasi rendah hingga sedang (25-50\%. Mineral lempung melimpah pada kedalaman ini hadir bersama mineral kalsit menggantikan plagioklas pada fragmen andesit dan mengisi rekahan-rekahan. Mineral sekunder lain pada kedalaman $570 \mathrm{mKu}$ yaitu kuarsa sekunder dan zeolit hadir bersama kalsit sebagai mineral pengisi rongga dan pecahan urat. $\mathrm{Di}$ kedalaman $574-650 \mathrm{mKu}$ terdapat gelas vulkanik yang sangat melimpah, sebagian teralterasi menjadi mineral lempung dan kalsit. Mineral opak dan oksida besi hadir tersebar tidak merata bersama klorit. Analisis mikroskopis (petrografi) di kedalaman $308 \mathrm{mKu}$ pada litologi breksi vulkanik teralterasi terdapat mineral sekunder klorit dan smektit (Gambar 10).
Himpunan Mineral Alterasi Ilit-SmektitEpidot. Himpunan mineral ini terdapat pada sampel cutting interval kedalaman 651$1410 \mathrm{mKu}$, pada litologi breksi vulkanik dan tuf terubah terdapat pada interval kedalaman 1274-1300 mKu. Mineral sekunder lempung hadir pada kedalaman ini yaitu smektit dan ilit. Mineral sekunder lainnya yaitu kalsit, klorit, zeolit, epidot, prehnit, adularia, anhidrit dan aktinolit. Plagioklas melimpah sebagai matriks sebagian terubah menjadi kalsit, kuarsa klorit dan mineral lempung. Mineral sekunder klorit, anhidrit, adularia, kalsit dan oksida besi dijumpai menggantikan sebagian mineral piroksen. Kuarsa sekunder, klorit, zeolit, kalsit dan adularia juga dijumpai sebagai mineral pengisi rongga dan pecahan urat. Mineral epidot hadir sebagai pecahan urat di kedalaman $820 \mathrm{mKu}$ bersama adularia dan zeolit yang mengisi rongga dan rekahan.

\section{Analisis X-Ray Diffraction (XRD) Permukaan dan Sumur}

Analisis XRD dilakukkan pada 3 (tiga) sampel batuan permukaan yaitu sampel dari daerah Pagar Alam 1 (PGA-1), Pagar Alam 2 (PGA-2), dan Muara Dua (MD). Sampel serbuk bor (cutting) diambil dari 3 (tiga) sumur yaitu sumur XD-1, XD-2 dan XD-3. Analisis XRD dilakukan untuk mengidentifikasi mineral-mineral yang ukurannya tidak dapat terlihat secara mikroskopik (petrografi) terutama pada kelompok mineral lempung

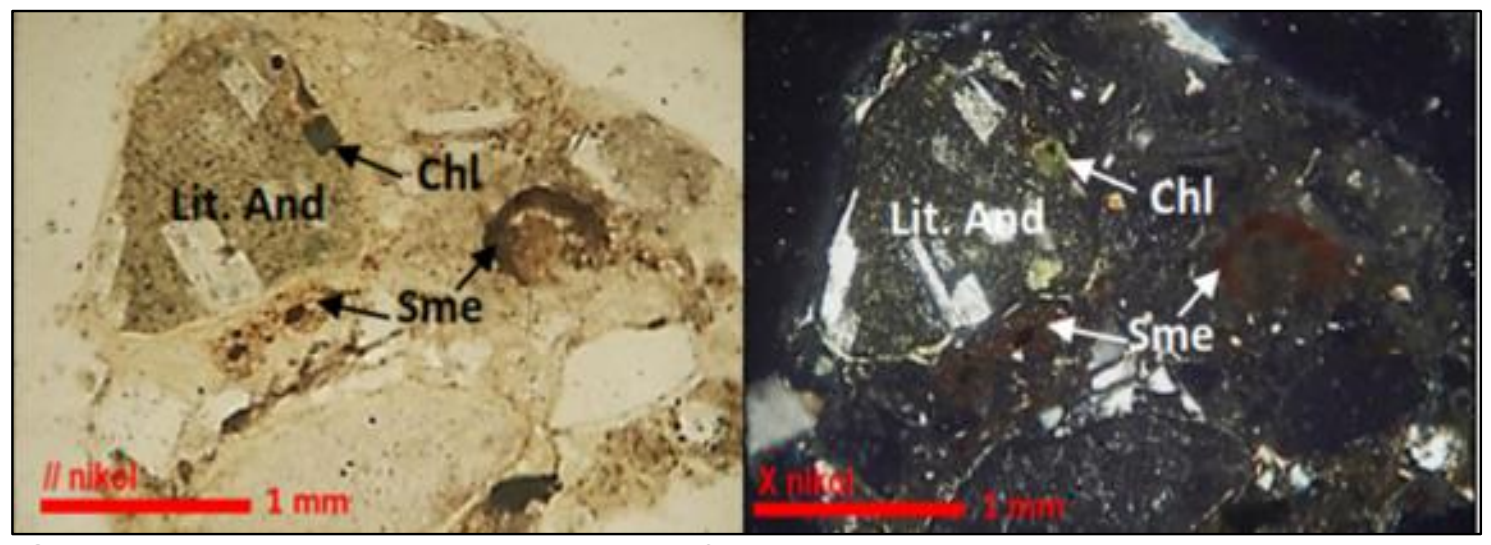

Gambar 10. Kenampakan mikroskopis, fragmen andesit dalam litologi breksi vulkanik teralterasi pada kedalaman $308 \mathrm{mKu}$, sampel cutting sumur XD-3 terdapat plagioklas yang terubah menjadi klorit (Chl) dan sebagian matrik telah terubah menjadi Smektit (Sme). 


\section{MAKALAH ILMIAH}

X_Ray Diffraction (XRD) Permukaan Hasil analisis XRD Pagar Alam 1 (PGA-1), pada kondisi sampel Ethylene Glicol (EG,) Air Dry (AD) dan Heating $(\mathrm{H})$ terdapat puncak grafik dominan mineral trydimite, crystobalite dan plagioklas (albite). Grafik clay mineral smektit masih dikenali pada ke tiga kondisi tersebut. Mineral kaolinit tidak terbaca lagi pada kondisi sampel di heating atau dipanaskan (Gambar 11).
Hasil analisis XRD Pagar Alam 2 (PGA-2) teridentifikasi puncak grafik dominan mineral kuarsa. Mineral alterasi hidrotermal lainnya yaitu clay mineral kaolinit dan smektit. Pada kondisi sampel Ethylene Glicol (EG,) Air Dry (AD) dan Heating (H) masih terdapat puncak grafik smektit dan kuarsa pada ke tiga kondisi tersebut. Puncak grafik mineral kaolinit tidak dijumpai lagi (Gambar 12).

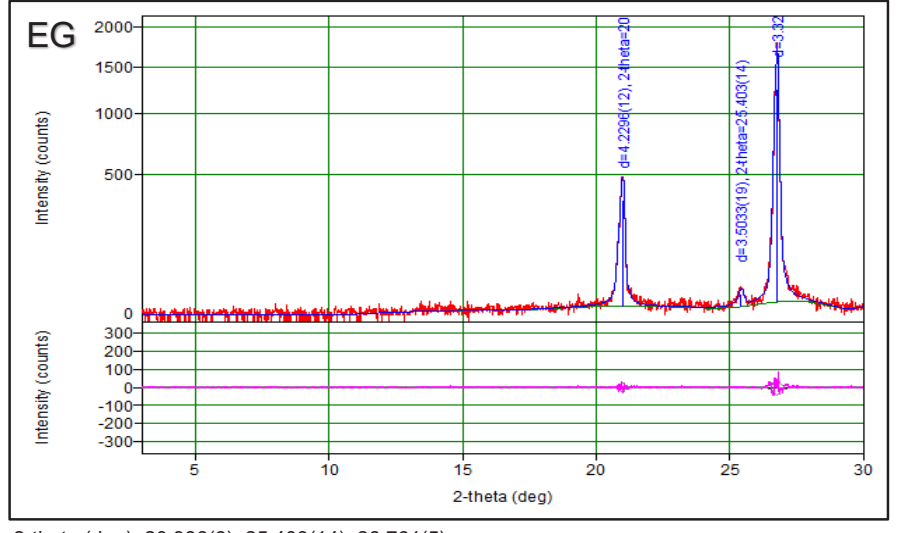

2-theta (deg): 20.986(6) :25.403(14):26.761(5)

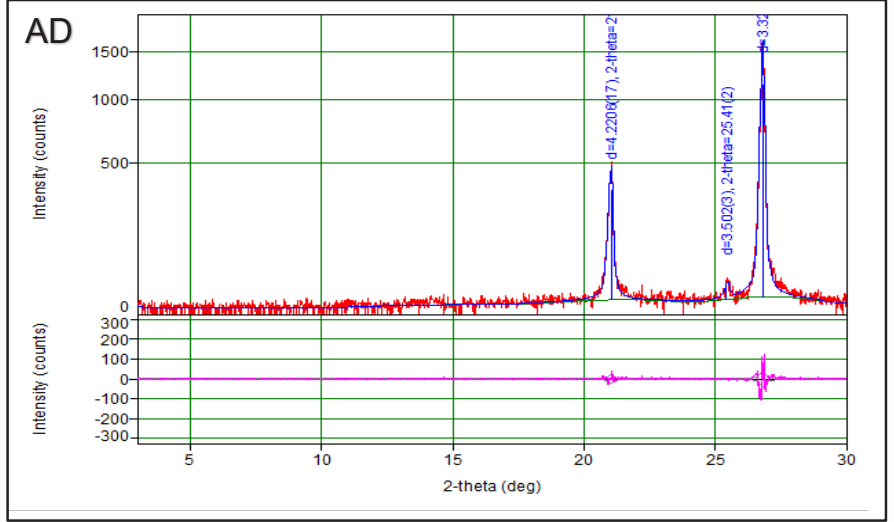

2-theta (deg): 21.031(9) :25.41(2):26.798(6)

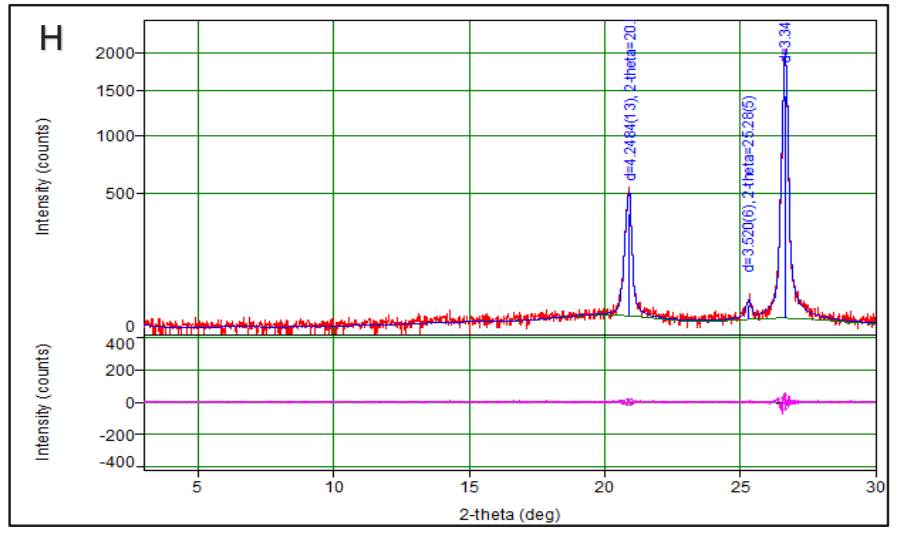

2-theta (deg): 20.892(7) :25.28(5) :26.641(4)

Gambar 11. Hasil XRD permukaan daerah Pagar Alam 1, pada kondisi EG, AD dan H 


\section{MAKALAH ILMIAH}

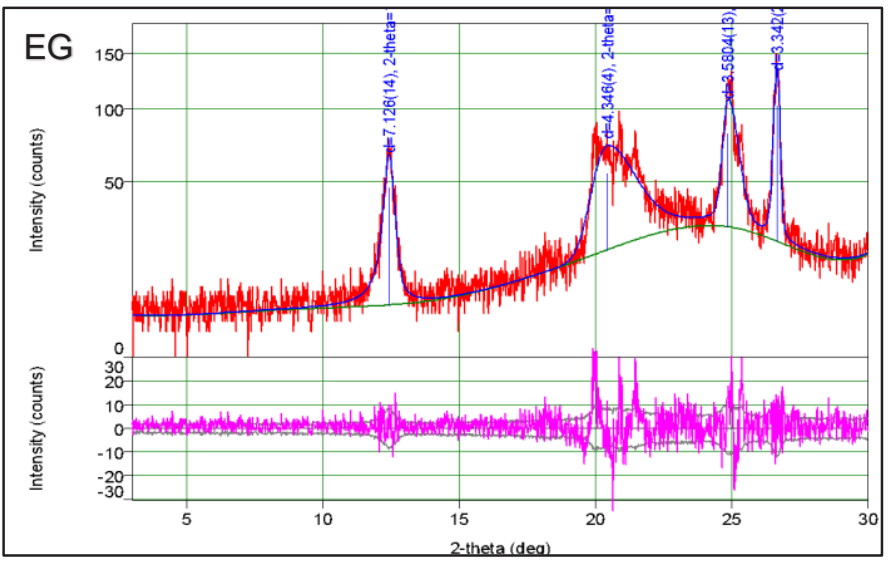

2-theta (deg):12.39(2):20.35(2):24.829(8):26.620(15)

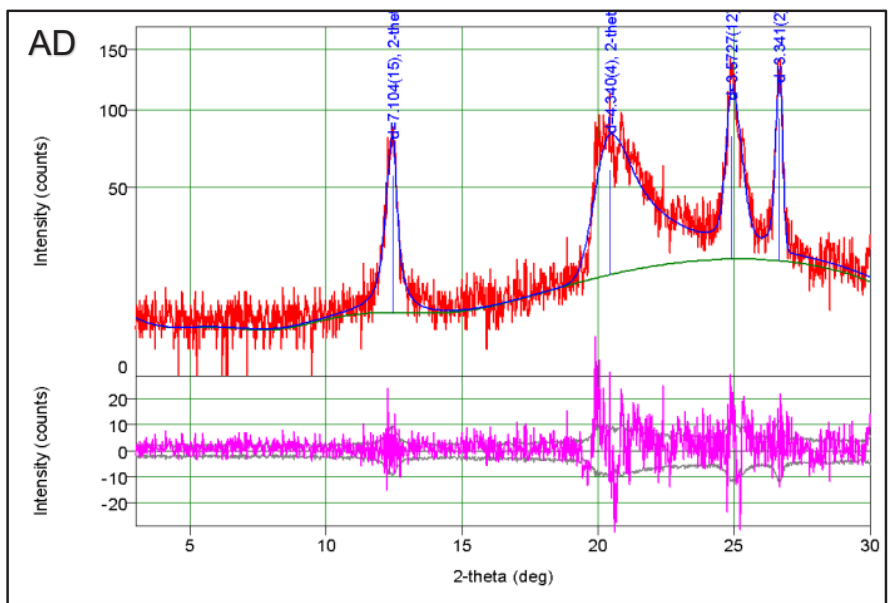

2-theta (deg) :12.45(3) :20.45(2):24.902(9) :26.656(18)

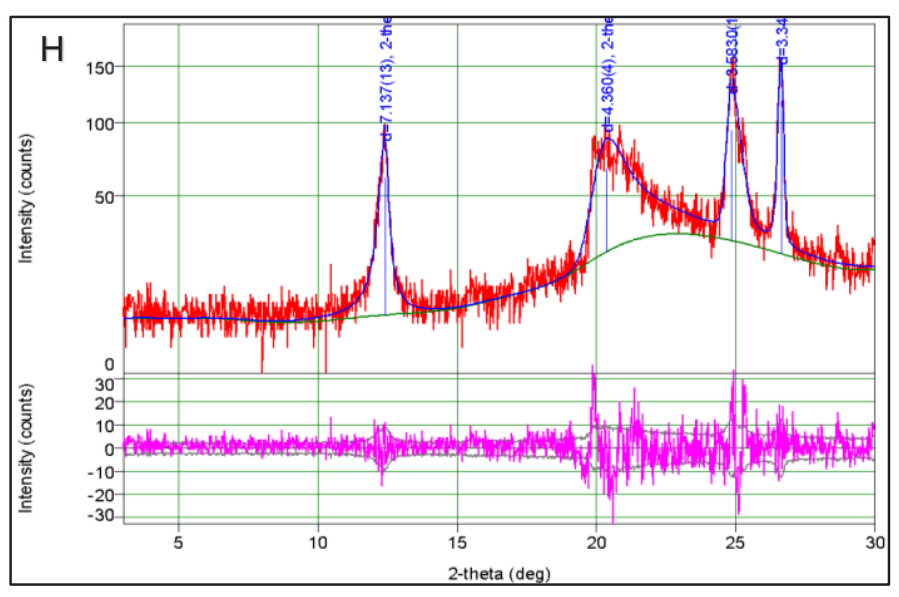

2-theta (deg): 12.41(2):20.416(19):24.847(9):26.651(17)

Gambar 12. Hasil XRD permukaan daerah Pagar Alam 2, pada kondisi EG, AD dan H. Puncak grafik kaolinit masih terbaca pada kondisi EG dan AD

Hasil analisis XRD Muara Dua (MD), teridentifikasi beberapa puncak grafik terlihat cukup jelas dengan kehadiran mineral plagioklas, kalsit dan jarosit. Pada kondisi sampel diberi larutan Ethylene Glicol (EG), Air Dry (AD) dan dipanaskan (heating) masih terlihat puncak mineral smektit dan kristobalit. Pada kondisi sampel di heating atau dipanaskan puncak grafik mineral smektit tidak dijumpai lagi, puncak grafik mineral kuarsa masih muncul untuk ke tiga kondisi $E G, A D$ dan $\mathrm{H}$ bersama mineral kalsit (Gambar 13). 


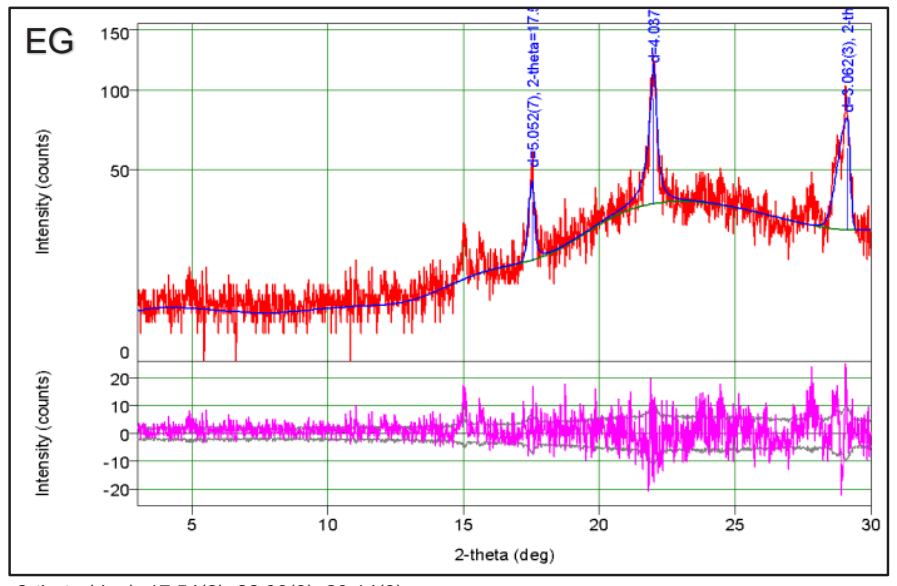

2-theta (deg):17.54(2):22.00(3):29.14(3)

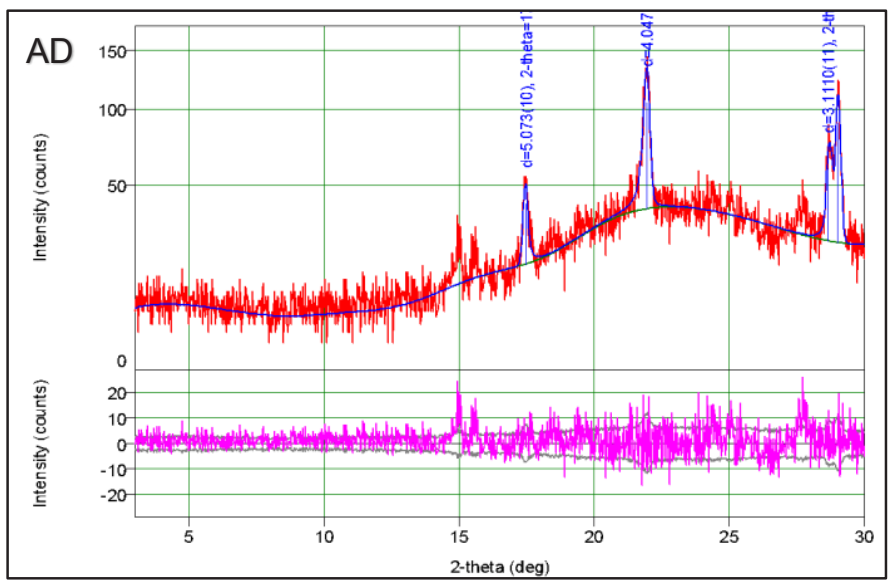

2-theta (deg) :17.47(3):21.94(2) :28.671(11):28.998(8)

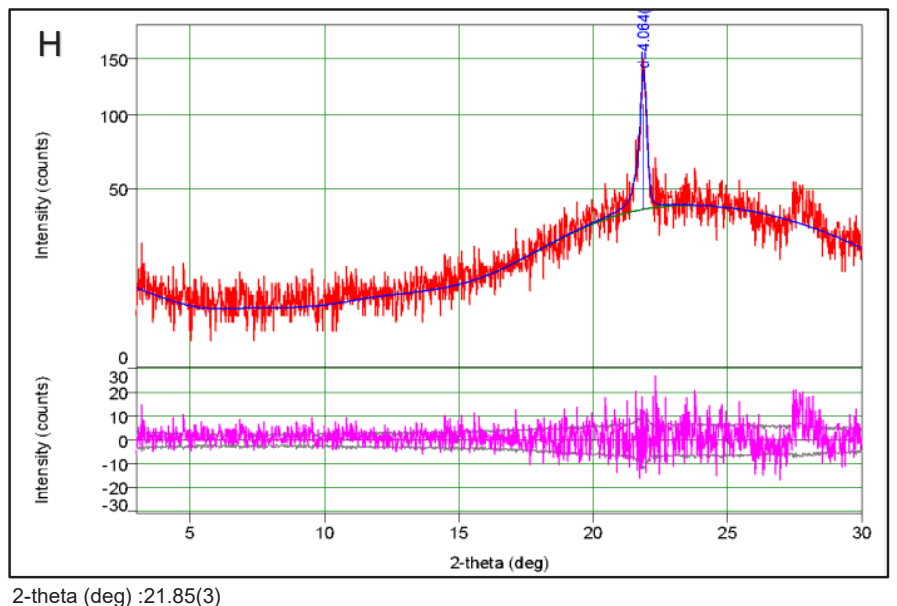

Gambar 13. Hasil XRD permukaan daerah Muara Dua pada kondisi EG, AD dan H, Puncak smektit masih terbaca pada kondisi AD bersama klorit

\section{X-Ray Diffraction (XRD) Sumur}

Hasil analisis XRD sumur XD-1 pada kedalaman $1254 \mathrm{mKu}$ memperlihatkan puncak grafik clay mineral smektit, ilit, smektit-ilit hadir pada tiga kondisi sampel diberi larutan Ethylene Glicol (EG), Air Dry (AD) dan di Heating $(\mathrm{H})$ atau dipanaskan (Gambar 14). 


\section{MAKALAH ILMIAH}

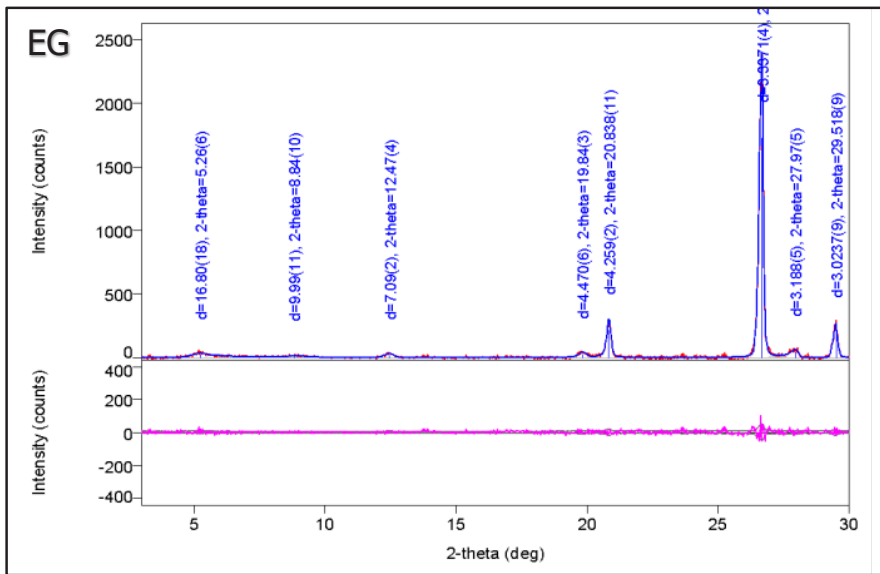

2-theta (deg):8.78(9):12.39(4):13.85(3):19.80(2):20.829(5):22.02(3):23.633(12):24.20(3):25.05(6):26.641(8):27.903(6)

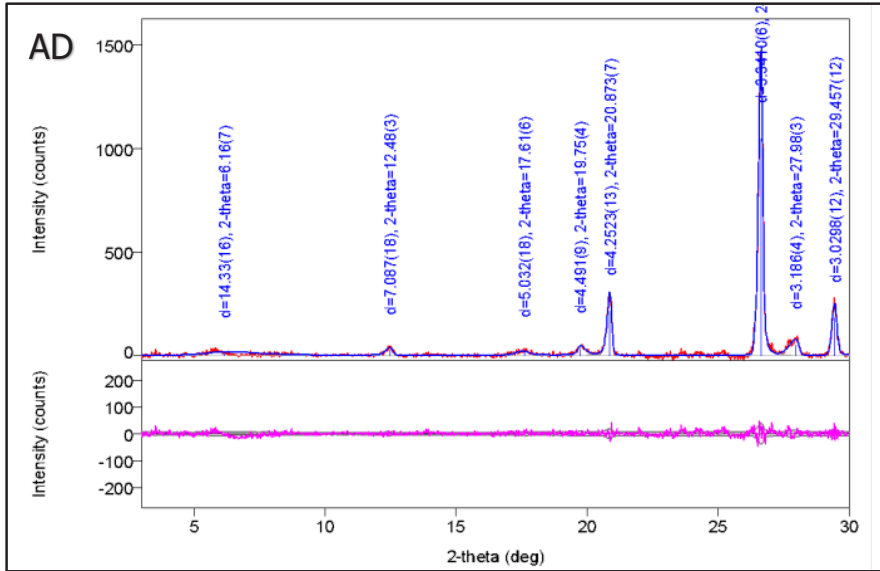

2-theta (deg):8.48(11):12.44(3):13.87(3):17.61(9):19.742(14):20.833(10):22.00(2):23.53(2):24.19(2):25.04(4):26.641(8):27.910(7):29.433(9)

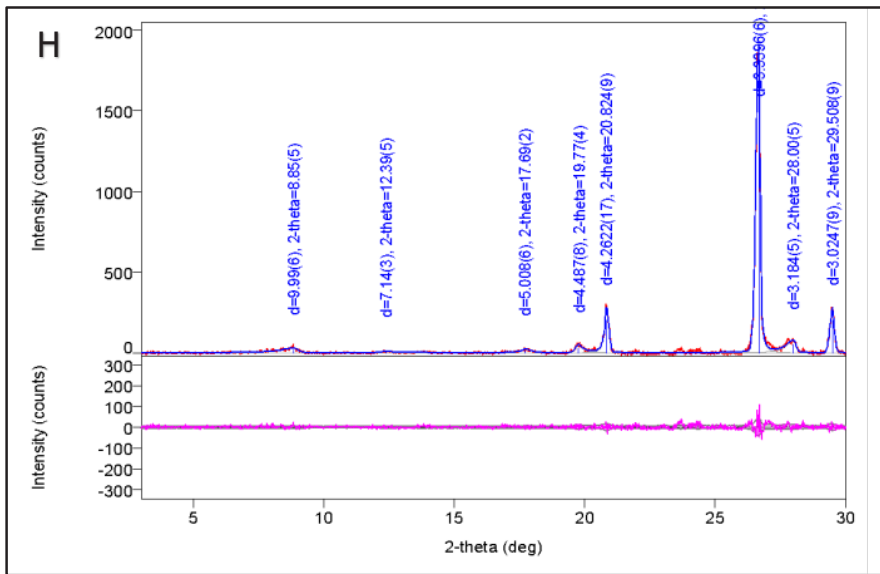

2-theta (deg):8.78(9):12.39(4):13.85(3):19.80(2):20.829(5):22.02(3):23.633(12):24.20(3):25.05(6):26.641(8): (27.903(6)

Gambar 14. Hasil analisis XRD cutting sumur XD-1, kedalaman $1254 \mathrm{mKu}$ memperlihatkan puncak grafik clay mineral: kaolinit, ilit, smektit pada kondisi EG, AD. Pada kondisi H, grafik kaolinit tidak terbaca

Hasil analisis XRD sumur XD-2 pada kedalaman $1208 \mathrm{mKu}$, memperlihatkan puncak grafik clay mineral kaolinit, smektit, ilit, smektit-ilit hadir kondisi sampel diberi larutan Ethylene Glicol (EG) dan Air Dry $(A D)$. Pada kondisi Heating $(H)$ mineral ilit dan smektit, monmorilonit-smektit masih dapat teridentifikasi hadir bersama mineral sekunder lain yaitu plagioklas, tridimit, pirofilit, kalsit dan jarosit. Grafik mineral kaolinit tidak hadir pada kondisi ter panaskan atau heating (Gambar 15). 


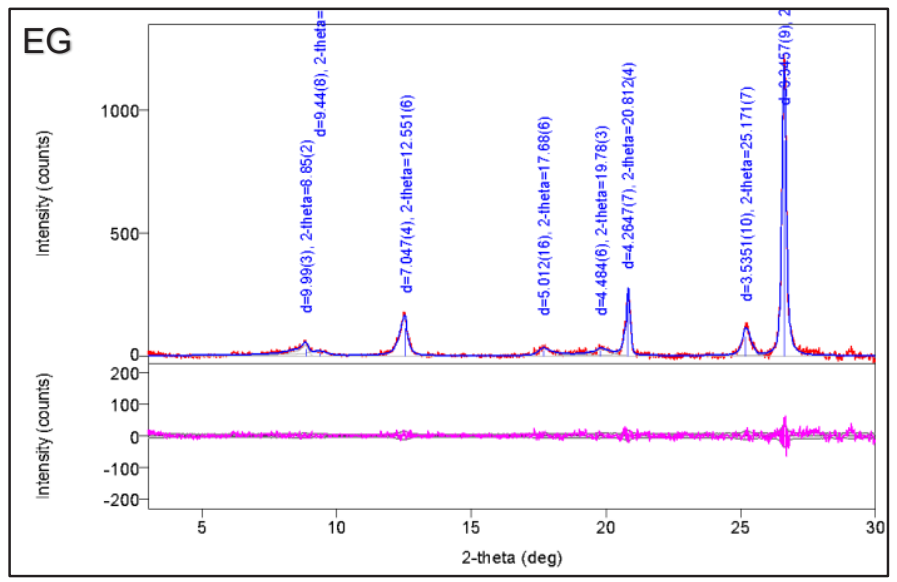

2-theta :8.85(2) :9.36(8):12.551(6):17.68(6):19.78(3) :20.812(4) :25.171(7): 26.621(7)

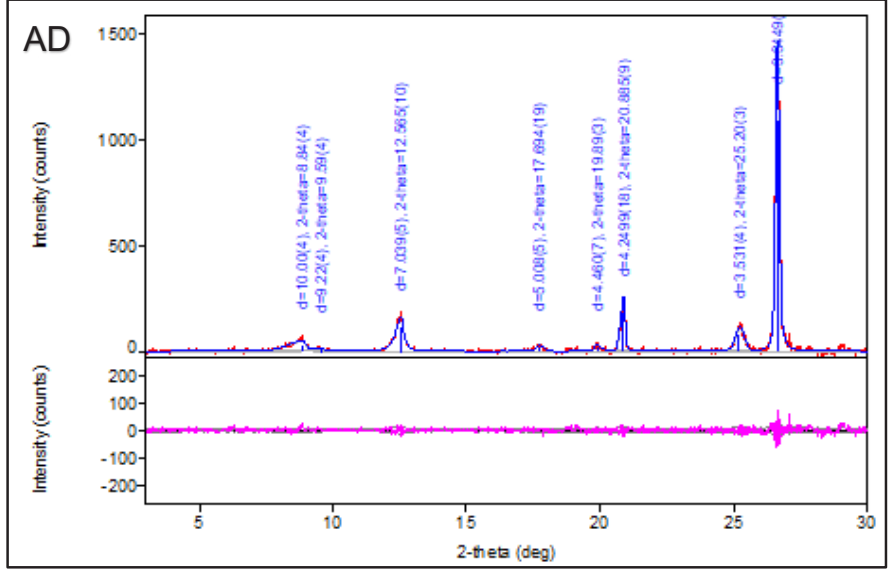

2-theta :8.84(4): :9.59(4):12.565(10):17.694(19):19.89(3):20.885(9):25.20(3): 26.628(6)

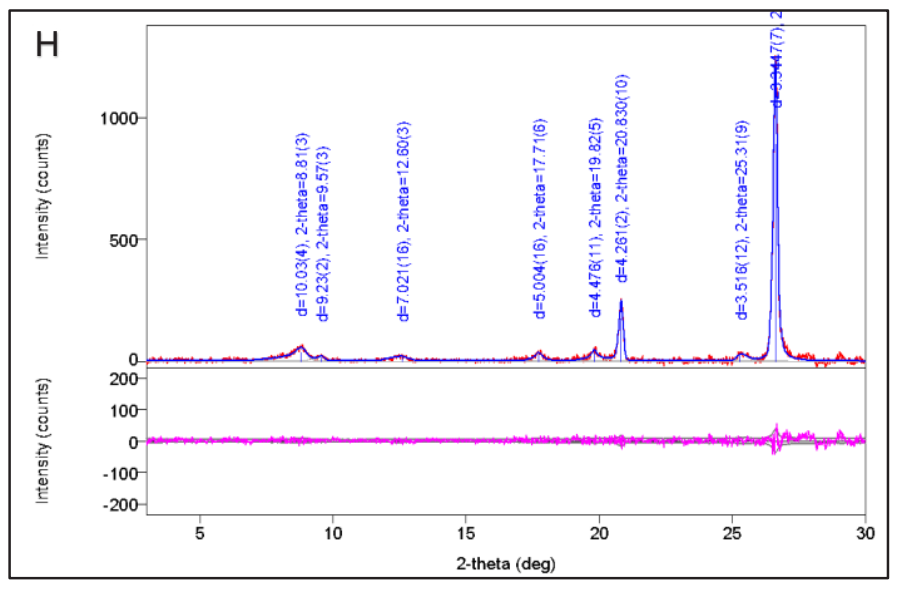

2-theta :8.81(3):9.57(3):12.60(3):17.71(6):19.82(5):20.830(10):25.31(9): 26.629(6)

Gambar 15. Hasil analisis XRD cutting sumur XD-2, kedalaman $1199 \mathrm{mKu}$, masih teridentifikasi puncak grafik clay mineral : ilit dan smektit pada kondisi EG, AD dan H

Hasil analisis XRD sumur XD-3 pada kedalaman $853 \mathrm{mKu}$, teridentifikasi puncak grafik clay mineral yaitu ilit, smektit, smektit-ilit dan kaolinit hadir pada kondisi sampel diberi larutan Ethylene Glicol (EG) dan Air Dry (AD). Pada kondisi Heating (H) puncak mineral ilit dan smektit masih teridentifikasi hadir bersama mineral sekunder lain yaitu plagioklas, tridimit, pirofilit, kalsit, jarosit dan klorit. Puncak grafik mineral kaolinit tidak hadir lagi pada kondisi di panaskan atau heating (Gambar 16). Log litologi dan himpunan mineral alterasi hidrotermal hasil analisis petrografi dan XRD dari cutting sumur XD-1, XD-2 dan XD-3 ditampilkan pada Gambar 17. 


\section{MAKALAH ILMIAH}

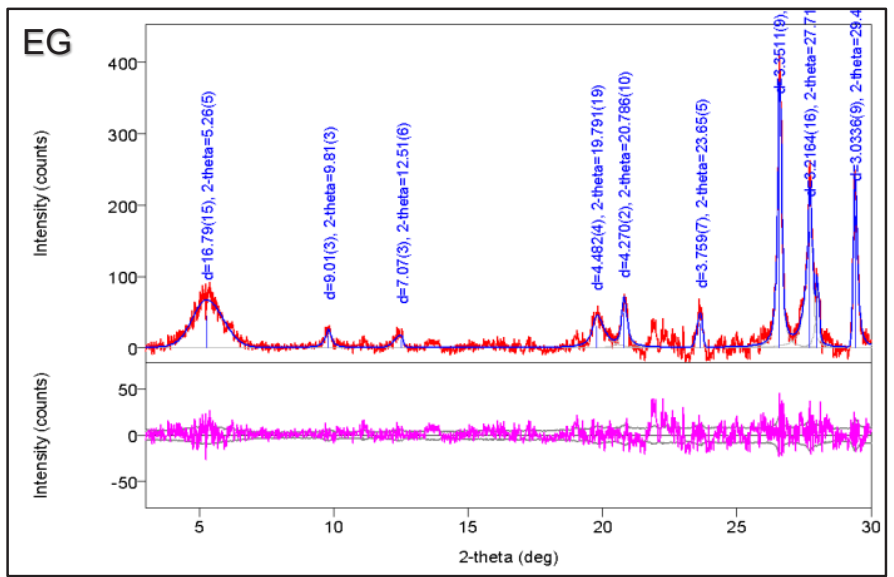

2-theta (deg):5.26(5):9.81(3):12.51(6): 19.791(19):20.786(10):23.65(5):26.578(7):27.712(14):27.999(9):29.419(9)

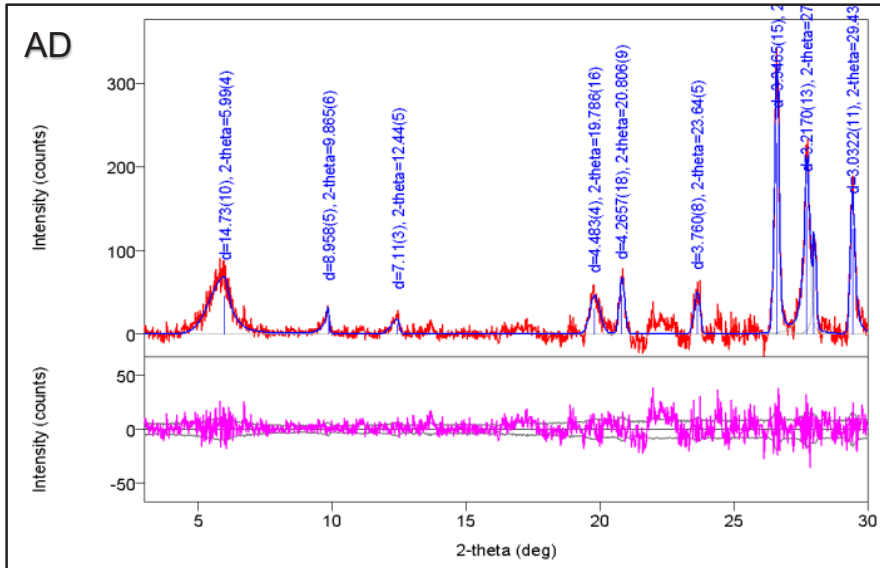

2-theta (deg):5.99(4):9.865(6):12.44(5):19.786(16):20.806(9):23.64(5):6.615(12):27.707(11):27.998(7):29.433(11)

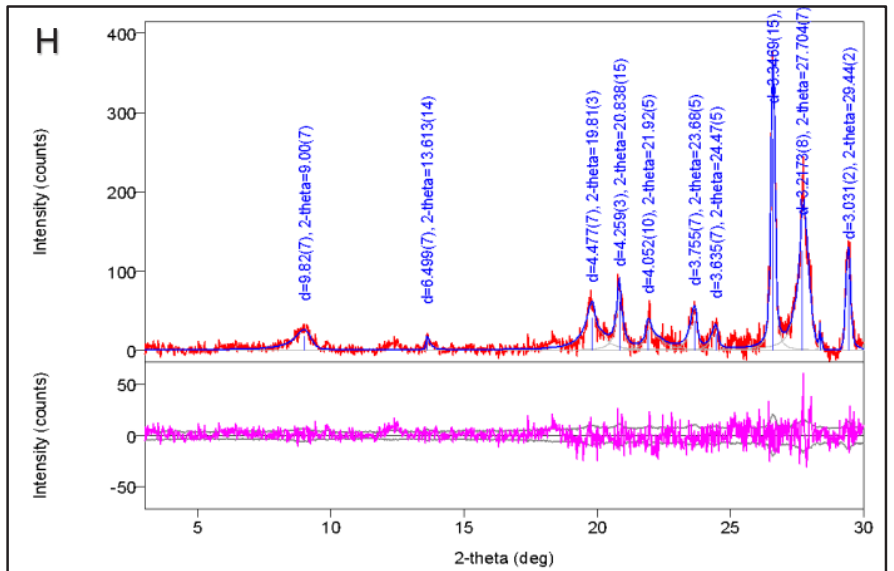

2-theta (deg):9.00(7):13.613(14): 19.81(3):21.838(15):21.92(5):23.68(5):24.47(5):26.611(12):27.704(7):28.380(9): (2)

Gambar 16. Hasil analisis XRD cutting sumur XD-3, kedalaman $1208 \mathrm{mKu}$,

memperlihatkan puncak grafik clay mineral : ilit dan smektit masih hadir pada kondisi $E G, A D$ dan $H$, bersama kuarsa sekunder, kristobalit dan K-Feldspars 

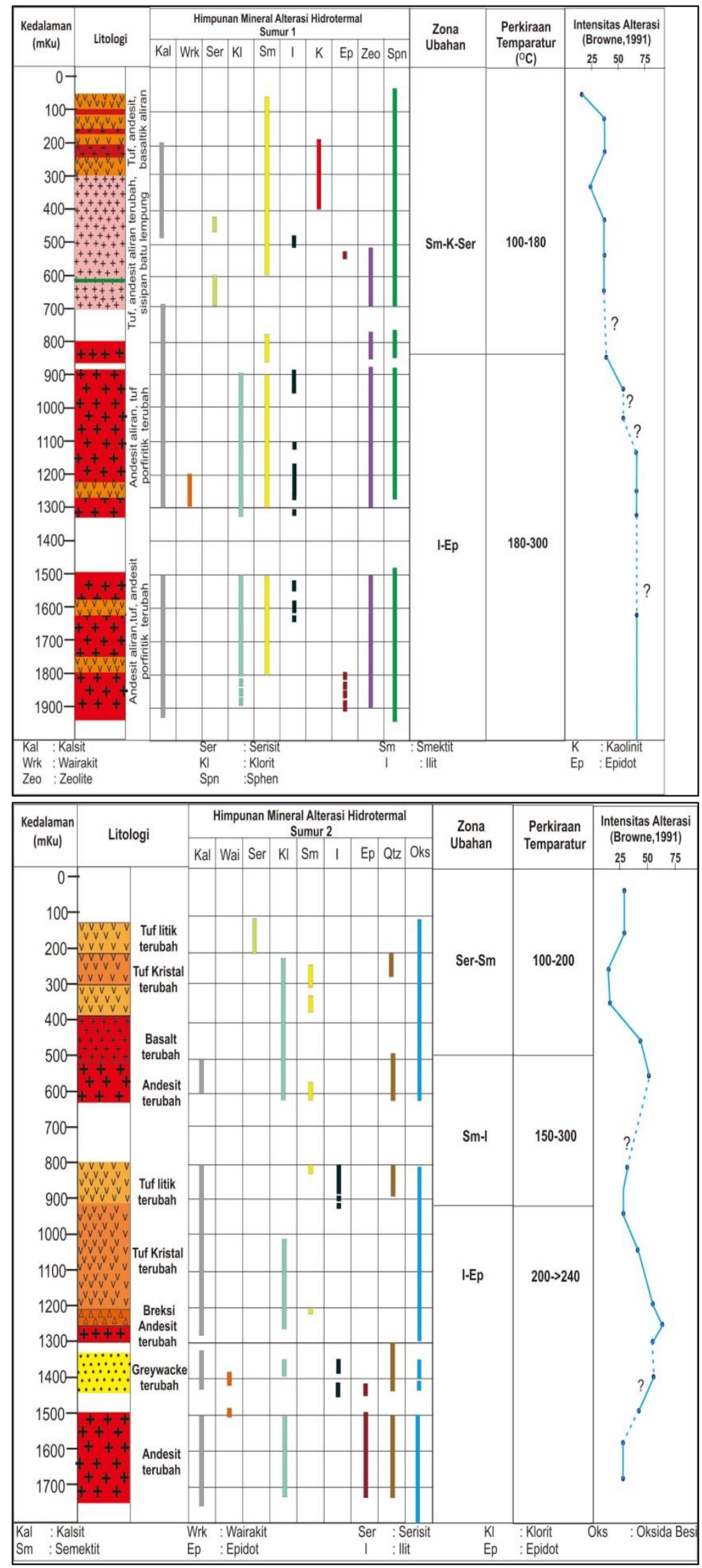


\section{MAKALAH ILMIAH}

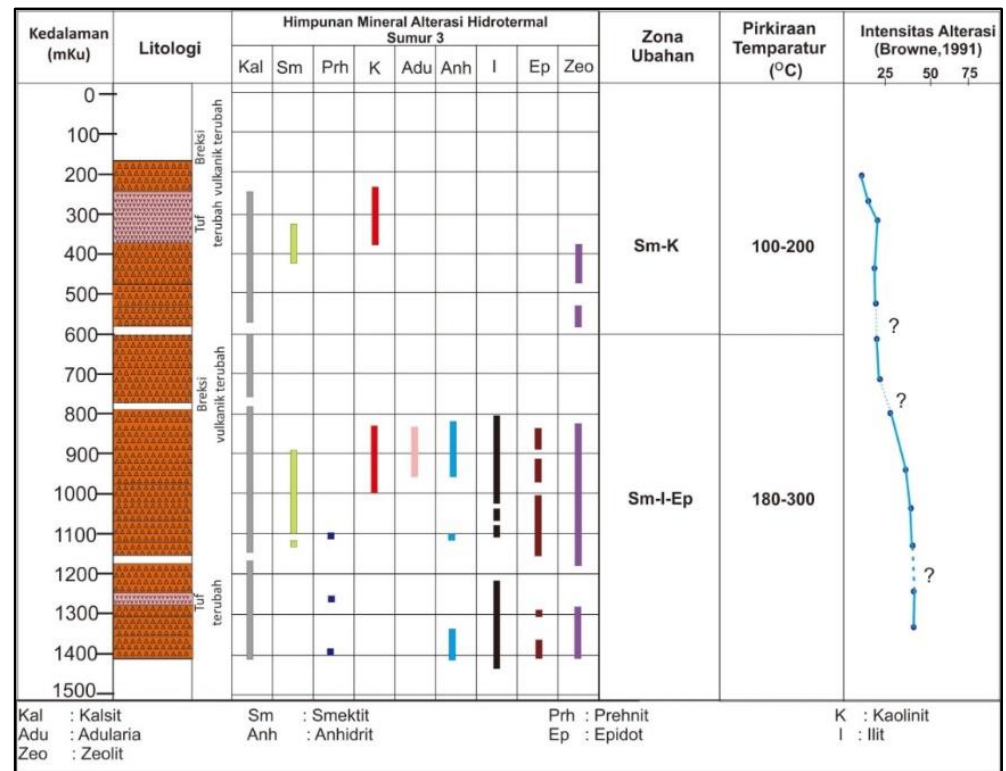

Gambar 17. Log Litologi dan Himpunan Mineral Alterasi Hidrotermal pada sumur XD-1, XD-2 dan XD-3, berdasarkan analisis petrografi dan XRD dapat diperkirakan zona reservoir memiliki kisaran temperatur $150^{\circ}-300^{\circ} \mathrm{C}$. Sumber : Serbuk bor (cutting) PT Pertamina Geothermal Energy

\section{PEMBAHASAN}

Alterasi hidrothermal di daerah penelitian memperlihatkan intensitas alterasi bervariasi mulai dari intensitas alterasi rendah hingga sedang $(25-50 \%)$ dan intensitas alterasi sedang hingga sangat kuat $(50 \geq 75 \%)$. Intensitas alterasi rendahsedang ditunjukkan oleh kondisi batuan dengan masa dasar dan fenokris/ fragmen batuan terubah tetapi tekstur asal batuan masih dapat dikenali. Alterasi mineral dengan intensitas sangat kuat secara mikroskopis diindikasikan oleh batuan yang tidak dapat dikenali baik jenis maupun tekstur batuan asalnya (Browne, 1991).

Batuan terubah dengan intensitas rendah sedang secara mikroskopis pada batuan andesit terubah masih dapat dikenali mineral primer plagioklas, yang hadir sebagai fragmen atau fenokris pada tuf, serta sebagian lagi sebagai pecahan mineral yang terubah menjadi epidot, klorit dan kuarsa sekunder, oksida dan kalsit.

Pada batuan yang telah mengalami alterasi dengan intensitas sangat kuat, jenis dan tekstur batuan asal sulit dikenali, dan kehijauan menggantikan tuf, gelas dan masa dasar serta fenokris pada andesit aliran dan andesit porfiritik. Mineral sekunder yang hadir antara lain smektit, serisit, ilit, klorit, zeolit, dan kalsit. Mineral sekunder tersebut hadir menggantikan mineral plagioklas, masa dasar juga sebagai pengisi rongga atau urat. Tekstur colloform sebagai hasil pengendapan kuarsa (Morrison, 1995). Jenis lempung berdasarkan analisis petrografi berupa smektit, ilit kaolinit dan serisit dengan jumlah yang bervariasi. Kehadiran mineral lempung tersebut di atas mengindikasikan bahwa fluida asam terbentuk di dekat permukaan. Hal ini didukung oleh terdapatnya mata air panas (hot spring) sebagai manifestasi panas bumi yang berada di daerah penelitian memiliki $\mathrm{pH}$ air 3-4. Peta kerangka geologi mencakup lokasi pengamatan litologi dan pengamatan manifestasi panas bumi permukaan di daerah penelitian secara keseluruhan ditampilkan pada Gambar 18. Plagioklas telah terubah menjadi mineral lempung berwarna kecoklatan. 


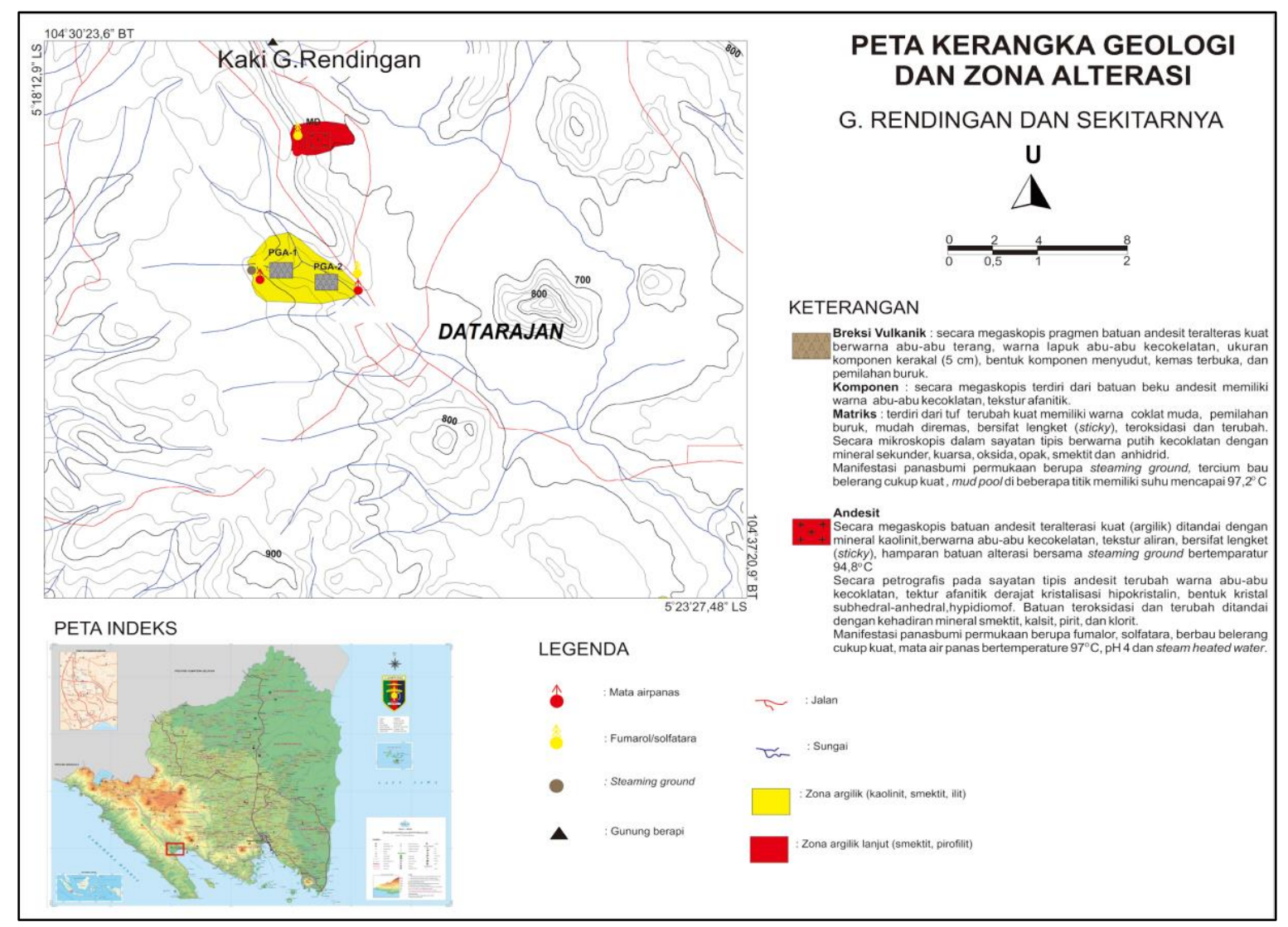

Gambar 18. Log Litologi dan Himpunan Mineral Alterasi Hidrotermal pada sumur XD-1,XD-2 dan XD-3, berdasarkan analisis petrografi dan XRD dapat diperkirakan zona reservoir memiliki kisaran temperatur $150^{\circ}-300^{\circ} \mathrm{C}$. Sumber : Serbuk bor (cutting) PT Pertamina Geothermal Energy

Berdasarkan hasil analisis petrografi dan XRD pada cutting sumur XD-1, XD-2, dan XD-3 memiliki himpunan mineral alterasi hidrotermal yang beragam yang dapat dipergunakan untuk memprediksi temperatur bawah permukaan.

Pada sumur XD-1 terdapat 2 (dua) himpunan mineral alterasi hidrotermal yaitu himpunan mineral smektit-kaolinit-serisit dan ilit-epidot. Himpunan Mineral smektitkaolinit-serisit terdapat pada interval kedalaman 100-818 mKu pada litologi tuf, andesit, basaltik, andesit aliran dan andesit porfiritik umunya terubah dengan intensitas rendah-sedang (20-50\%). Kehadiran mineral serisit menunjukkan adanya pengaruh fluida asam di kedalaman tersebut. Mineral sekunder lainnya yang hadir pada kedalaman ini yaitu kalsit, piropilit, zeolit, kuarsa sekunder, mineral opak dan sfen. Temperatur bawah permukaan pada interval kedalaman ini diperkirakan pada kisaran $100^{\circ}-180^{\circ} \mathrm{C}$ dan $\mathrm{pH}$ asam.

Himpunan mineral ilit-epidot pada sumur XD-1 terdapat pada interval kedalaman 908-1980mKu pada litologi tuf, andesit aliran andesit porfiritik dan sisipan batulempung pada kedalaman $1104 \mathrm{mKu}$ dan 1305 mKu. Kemunculan mineral ilit dan epidot pada kedalaman $501 \mathrm{mKu}$ diperkirakan sebagai mineral relict.Mineral sekunder lain yang hadir antara lain klorit, kalsit, kuarsa sekunder, zeolit, mineral opak wairakit dan sfen. Di beberapa kedalaman klorit, kalsit dan zeolit dijumpai sebagai vein mineral. Kehadiran wairakit mengindikasikan bahwa batuan di kedalaman tersebut bersifat permeabel (Suharno dan Browne, 2000). Kehadiran mineral kalk-silikat epidot menandakan daerah kedalaman ini mempunyai suhu tinggi atau indikator temperatur yang baik pada zona reservoir. Kisaran temperatur 
bawah permukaan sumur XD-1 diperkirakan berkisar dari $180^{\circ}-300^{\circ} \mathrm{C}$ (Gambar 19 A) dengan pH netral sedikit asam (Thomson, 1996).

Pada sumur XD-2 terdapat 3 (tiga) himpunan mineral alterasi hidrotermal yaitu himpunan mineral smektit-serisit, smektitilit dan ilit-epidot.

a. Himpunan mineral smektit-serisit terdapat pada interval kedalaman 125-518 mKu pada litologi tuf litik, tuf kristal, basalt, dan andesit terubah dengan intensitas alterasi rendah-sedang (20-44\%). Mineral sekunder yang hadir yaitu serisit, smektit, oksida besi, mineral opak dan kuarsa sekunder, Kehadiran mineral serisit mengindikasikan larutan asam berasal dari fluida kondesat turun ke sistem hidrothermal melalui media rekahan.

b. Himpunan mineral smektit-ilit terdapat pada interval kedalaman $519-908 \mathrm{mKu}$ pada litologi breksi tuf terubah, tuf litik, tuf kristal, andesit dan greywacke terubah. Intensitas alterasi pada interval kedalaman tersebut sedang (24-35\%).Mineral sekunder hadir pada interval kedalaman ini antara lain kalsit, klorit, kuarsa sekunder, smektit mineral opak dan oksida besi. Himpunan mineral smektit-ilit ini diperkirakan memiliki temperatur pada kisaran $180^{\circ}-300^{\circ} \mathrm{C}$ dan $\mathrm{pH}$ netral. Adanya zona hilang sirkulasi terjadi pada interval kedalaman 639-817 mKu mengindikasikan pada kedalaman tersebut memiliki permeabilitas yang baik pada batuan dikarenakan oleh perkembangan struktur geologi.

c. Himpunan mineral ilit-epidot terdapat pada interval kedalaman 909-1748 mKu. Epidot dicirikan oleh warna hijau kecoklatan mempunyai bentuk kristal tidak sempurna. Pembentukan epidot muncul pada temperatur $200-250^{\circ} \mathrm{C}$ (Reyes, 1990). Wairakit umumnya muncul pada temperatur $220^{\circ}-310^{\circ} \mathrm{C}$. Wairakit terdapat pada batuan graywacke menyisip pada andesit terubah di kedalaman $1421 \mathrm{mKu}$ dan $1451 \mathrm{mKu}$. Kehadiran mineral wairakit sebagai penciri zona permeabel (Suharno dan Browne, 2000). Mineral sekunder yang hadir antara lain ilit, epidot, kalsit, klorit, mineral opak, wairakit dan kuarsa sekunder. Kehadiran epidot dan wairakit digunakan sebagai indikator zona reservoir. Adanya zona hilang sirkulasi mulai kedalaman $640-800 \mathrm{mKu}$ dan hilang sirkulasi dijumpai kembali pada interval kedalaman 1272-1299 mKu, 1300$1342 \mathrm{mKu}$ yang menerus sampai di kedalaman 1633-1722mKu menandakan pada kedalaman dengan himpunan mineral alterasi tersebut memiliki permeabilitas baik (Siahaan, 2015). Kehadiran mineral kalk-silikat epidot sebagai mineral indikator temperatur yang baik (Gambar $19 \mathrm{~B}$ ).

Pada sumur XD-3 memiliki 2 (dua) himpunan mineral alterasi hidrotermal yaitu himpunan mineral smektit-kaolinit dan himpunan mineral ilit-smektit-epidot. Himpunan mineral smektit-kaolinit terdapat pada interval kedalaman $178-650 \mathrm{mKu}$ pada litologi breksi vulkanik dan tuf terubah dengan intensitas alterasi rendah - sedang (20-27\%). Mineral sekunder yang hadir antara lain kalsit, smektit, klorit dan zeolit.Kehadiran kalsit yang melimpah mengindikasikan bahwa himpunan mineral ini mengalami proses pendidihan (boiling) (Simmons, 1993).

Himpunan mineral smektit-kaolinit ini diperkirakan memiliki temperatur bawah permukaan pada kisaran $100-200^{\circ} \mathrm{C}$ dan $\mathrm{pH}$ asam. Kehadiran mineral zeolit dapat dipergunakan sebagai indikator temperatur yang baik. Kemunculan mineral zeolit sangat tergantung dengan temperatur saat pembentukannya (Brown, 1978).

Himpunan mineral ilit-smektit-epidot terdapat pada interval kedalaman 700$1410 \mathrm{mKu}$ pada litologi breksi vulkanik terubah dengan fragmen andesit dan matrik gelas vulkanik dan tuf terubah dengan intensitas alterasi sedang (25$40 \%)$. Mineral sekunder yang hadir antara lain kalsit, klorit, zeolit, epidot, prehnit, adularia dan anhidrit, Mineral kalsit kuarsa sekunder dan klorit selain sebagai pengganti plagioklas dan masa dasar juga terdapat sebagai vein mineral. Banyaknya vein mineral mengindikasikan bahwa 
batuan telah mengalami rekahan. Hadirnya mineral adularia sebagai penciri dari zona permeabilitas yang baik (Browne, 1984). Kehadiran mineral epidot dan prehnit dapat digunakan sebagai indikator zona reservoir memiliki temperatur yang baik dengan kisaran temperatur $180^{\circ}-300^{\circ} \mathrm{C}$ (Gambar $19 \mathrm{C})$.

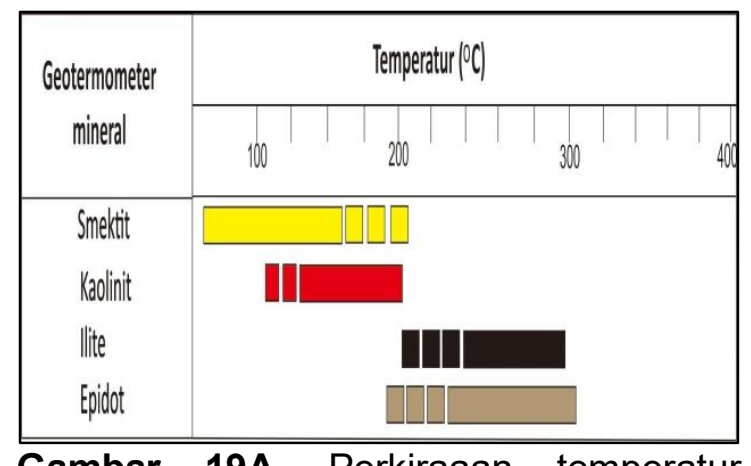

Gambar 19A. Perkiraaan temperatur bawah permukaan sumur XD-1, berdasarkan himpunan mineral alterasi hidrotermal.

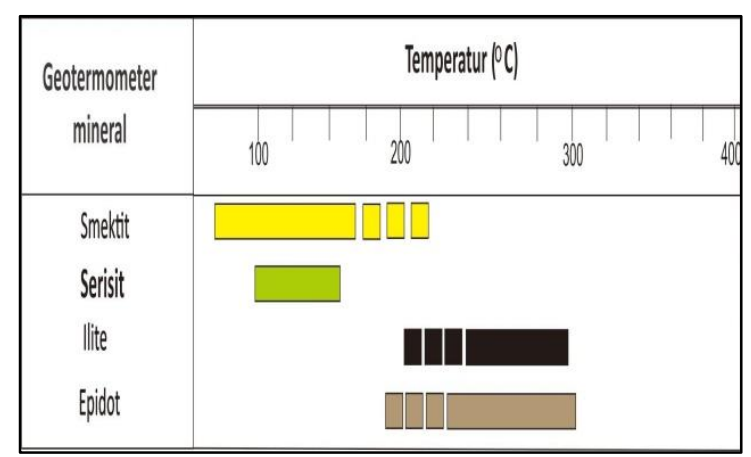

Gambar 19B. Perkiraaan temperatur bawah permukaan sumur XD-2, berdasarkan himpunan mineral alterasi hidrotermal.

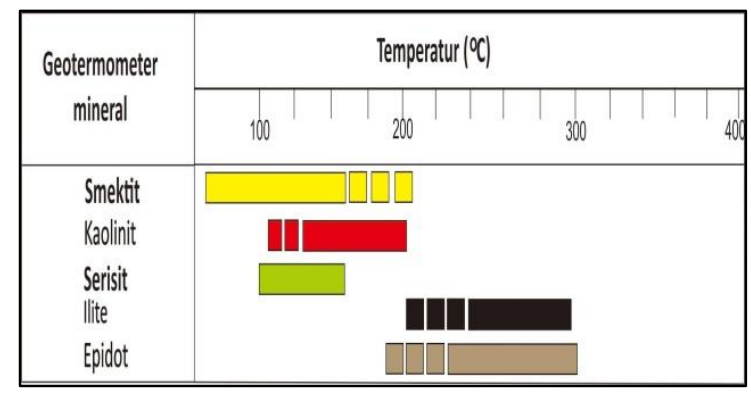

Gambar 19C. Perkiraan temperatur bawah permukaan sumur XD-3, berdasarkan himpunan mineral alterasi hidrotermal.

\section{KESIMPULAN}

Berdasarkan hasil analisis petrografi dan $X$-Ray Diffraction (XRD) sampel batuan permukaan menunjukkan bahwa di daerah penelitian memiliki variasi himpunan mineral alterasi hidrotermal dengan kehadiran mineral sekunder kaolinit, smektit, ilit, anhidrit, adularia, kalsit, kuarsa sekunder dan mineral kalk-silikat epidot. Hilangnya mineral kaolinit dan smektit pada kondisi terpanaskan (heating) mencerminkan mineral tersebut tidak stabil pada temperatur tinggi. Dari hasil analisis petrografi dan $X$-Ray Diffraction (XRD) pada sampel serbuk bor (cutting) sumur XD-1 mempunyai himpunan mineral smektit-kaolinit-serisit dan ilit-epidot. Sumur XD-2 mempunyai himpunan mineral smektit-serisit, smektit-ilit dan ilit-epidot. Sedangkan pada sumur XD-3 memiliki himpunan mineral smektit-kaolinit dan ilitsmektit-epidot. Hal tersebut memperlihatkan bahwa semakin dalam kedalaman sumur, fluida semakin netral. Zona reservoir di daerah penelitian diperkirakan pada kedalaman 700 - 1900 mKu dengan kehadiran mineral kalk-silikat seperti mineral epidot, wairakit dan prehnit. Temperatur bawah permukaan berkisar antara $150-300^{\circ} \mathrm{C}$ pada masa awal pembentukannya. Kehadiran mineral sekunder adularia mengindikasikan batuan di daerah penelitian memiliki permeabilitas yang baik.

\section{UCAPAN TERIMAKASIH}

Terimakasih penulis sampaikan kepada PT. Pertamina Geothermal Energy (PGE) yang telah memberikan izin penelitian, dan terimakasih kepada semua pihak yang telah banyak membantu hingga penelitian terlaksana dengan lancar.

\section{DAFTAR PUSTAKA}

Browne, R.P.L., 1978. Hydrotthermal Alteration in active geothermal fields, Annual Reviews, Earth Planet Science, Annual Reviews Inc., p.22950. 


\section{MAKALAH ILMIAH}

Browne, R.P.L., 1984. Hydrotthermal Alteration Lecture Notes, Geothermal Institute, University of Auckland, New Zealand.

Browne, R.P.L., 1991. Hydrothermal Alteration and Geothermal System, The University of Aucland, New Zealand.

Hochstein, M.P., and Browne P.R.L., 2000, Surface Manisfestation System with Volcanic Heat Sources. Encyclopedia of Volcanoes, Academic Press, p 835-853.

Guilbert, J. M., and Park Jr. C.F., 1986, The geology of ore deposits. New York W.H. Libraries Australia., Vol 96 No. 1.

Kamah, M.Y., 2001, Mapping Permeability Potential as Target Reservoir at Geothemal Ulubelu Field. Proceeding of the $5^{\text {th }}$ INAGA Annual Scientific Conference And Exhibitions, Yogyakarta.

Masdjuk. 1990. Laporan Geologi Daerah Way Panas dan Ulubelu, Lampung Selatan. Divisi panas bumi, Direktorat Eksplorasi dan Produksi, Pertamina (Tidak diterbitkan).

Morrison, G., Dong Guoyi and Subash Jaireth. 1995. Textural Zoning in Epithermal Quartz Veins. Klondike Exploration Service.

Reyes, A.G., 1990. Petrology of Philippine Geothermal System and The Application of Alteration Mineralogy to their Assessment. United Nations University, Geothermal Training Programme : Reykjavanik.
Siahaan, E.E., Sasradipoera, D.S Silitonga,T.H., Pamel, C., Koestono, $\mathrm{H}$, Mubarok, M.H., Rifki, G.,2015.Success Develop-ment Drilling in Ulubelu Green Field in South Sumatra Based on Geological Structure Evidence, Generate 4X55MW. Proceedings World Geothermal Congress 2015, Melbourne, Australia.

Simmons, S.F., and B.W Christenson. 1993. Towards A Unified Theory on Calcite Formation in Boiling Geothermal System. Proceeding 15th NZ Geothermal Workshop, pg 145-148.

Suharno and Browne, P.R.L., 2000. Subsurface Hydrothermal Alteration at The Ulubelu Geothermal Field, Lampung, Southern Sumatra, Indonesia, Standford University, California.

Thomson, A.J.B., and Thomson, J.F.H., 1996. Atlas of Alteration, a Field and Petrographic Guide to Hydrothermal Alteration Minerals., Geological Association of Canada., I 16 hal.

Van Bemmelen, RW., 1949. The Geology of Indonesia, volume I.A. The Hague Martinus Nijhoff, Nederland.

Yosana V., Rosana F. M., Haryanto A. D., Koestono, H., 2017. Himpunan Alterasi Hidrotermal pada sumur penelitian " $V \quad Y \quad Z$ " lapangan Kamojang Jawa Barat, Indonesia.Padjadjaran. Geoscience Journal. Vol no.2 pp 164-171.

$\begin{array}{ll}\text { Diterima } & : 16 \text { Oktober } 2018 \\ \text { Direvisi } & : 30 \text { Oktober } 2018 \\ \text { Disetujui } & : 30 \text { November } 2018\end{array}$

